\title{
PEMANTAUAN DAN PENGENDALIAN KERUSAKAN LAHAN UNTUK PRODUKSI BIOMASSA DI KABUPATEN KUNINGAN JAWA BARAT
}

\author{
Andrianto Kusumoarto ${ }^{1}$, Ryan Hidayat ${ }^{2}$ \\ ${ }^{1}$ Universitas Indraprasta PGRI, Program Studi Arsitektur \\ andrianto.kusumoarto@unindra.ac.id \\ ${ }^{2}$ Universitas Indraprasta PGRI, Program Studi Arsitektur \\ ryan.hidayat@unindra.ac.id
}

\begin{abstract}
:
Soil damage for biomass production occurs in several areas in Kuningan Regency. This study aims to provide complete information on soil damage for Biomass production in Kuningan Regency through the Geography Information System (GIS). In addition, it provides information on prevention efforts and models for preventing land damage. The method of approach to this research is the survey method. The method of work carried out to assess the criticality of land is based on the Technical Guidance Document for Preparation of Critical Land Spatial Data in 2004 by the Directorate General of Land Rehabilitation and Social Forestry (RLPS) and Letter of Director General RLPS No. S.296/V-SET / 2004 dated October 5, 2004. Based on the results of GIS analysis, it can be identified that almost all villages in general experience conditions and damage status that is included in the potential of "moderate". More villages in moderate potential are Cisantana Village, Gunungsirah Village, Padabeunghar Village, Puncak Village, Sangkanherang Village, Sayana Village, Seda Village, Segarahiang Village, Sukamukti Village, Sukasari Village, and Trijaya Village. Whereas Babakan Mulya Village is more in the potential of minor damage. This condition is caused by changes in land use and cover conditions. Soil damage can be reduced and prevented through an effort called land conversion. Land conversion is the maintenance and protection of land on a regular basis to reduce and prevent damage to land by preservation. Soil conservation methods are carried out in 3 ways, namely agronomic, mechanical, and chemical conservation.
\end{abstract}

Key Words: Land Damage, Biomass Production, Geographic Information Systems, Soil and Land Conservation

\begin{abstract}
Abstrak :
Kerusakan tanah untuk produksi biomassa terjadi di beberapa kawasan di Kabupaten Kuningan Penelitian ini bertujuan untuk menyediakan informasi yang lengkap mengenai kerusakan tanah untuk produksi Biomassa di Kabupaten Kuningan melalui Sistem Informasi Geografi (SIG). Selain itu, menyediakan informasi upaya penanggulangannya dan model pencegahan kerusakan tanah. Metode pendekatan penelitian ini adalah metode survai. Metode kerja yang dilakukan untuk penilaian tingkat kekritisan lahan berdasarkan pada dokumen Petunjuk Teknis Penyusunan Data Spasial Lahan Kritis tahun 2004 oleh Direktorat Jenderal Rehabilitasi Lahan dan Perhutanan Sosial (RLPS) dan Surat Direktur Jenderal RLPS No. S.296/V-SET/2004 tanggal 5 Oktober 2004. Berdasarkan hasil analisis SIG, dapat diidentifikasi bahwa hampir seluruh desa secara umum mengalami kondisi dan status kerusakan yang masuk dalam potensi "sedang". Desa-desa yang lebih banyak berada dalam potensi kerusakan sedang adalah Desa Cisantana, Desa Gunungsirah, Desa Padabeunghar, Desa Puncak, Desa Sangkanherang, Desa Sayana, Desa Seda, Desa Segarahiang, Desa Sukamukti, Desa Sukasari, dan Desa Trijaya. Sedangkan Desa Babakan Mulya lebih banyak berada dalam potensi kerusakan ringan. Kondisi ini diakibatkan oleh kondisi perubahan penggunaan dan tutupan lahan. Kerusakan tanah dapat dikurangi dan dicegah melalui suatu upaya yang disebut konversi tanah. Konversi tanah adalah pemeliharaan dan perlindungan terhadap tanah secara teratur guna mengurangi dan mencegah kerusakan tanah dengan cara pelestarian. Metode konservasi tanah dilakukan dengan 3 cara, yaitu konservasi secara agronomis, mekanis, dan kimiawi.
\end{abstract}

Kata Kunci : Kerusakan Lahan, Produksi Biomassa, Sistem Informasi Geografi, Konservasi tanah dan Lahan 


\section{PENDAHULUAN}

Sumber daya tanah di Kabupaten Kuningan memiliki peran strategis baik saat ini maupun pada masa yang akan datang. Kerusakan tanah untuk produksi biomassa terjadi di beberapa kawasan di Kabupaten Kuningan. Pengendalian kerusakan tanah untuk produksi biomassa di kabupaten ini sangat diperlukan mengingat aktivitas penggunaan lahan untuk pertanian sangat intens dalam meningkatkan kesejahteraan masyarakat. Kualitas tanah mampu mencerminkan tingkat produktivitas dalam mendorong pembangunan (pertanian) untuk memenuhi kebutuhan pangan dan non pangan (Maier et al., 2015; Laurance, Sayer, dan Cassman 2014; Fahma dan Kristyanto, 2016).

Tanah merupakan sumber daya alam yang terbatas dan senantiasa mendapatkan tekanan yang semakin besar untuk memenuhi kebutuhan penduduk akan sandang, papan dan pangan yang semakin meningkat. Berdasarkan Undang-undang Nomor 32 Tahun 2009 tentang Perlindungan dan Pengelolaan Lingkungan Hidup disebutkan bahwa perusakan lingkungan adalah tindakan yang menimbulkan perubahan langsung maupun tidak langsung terhadap sifat fisik dan/atau hayatinya yang mengakibatkan lingkungan hidup tidak berfungsi lagi dalam menunjang pembangunan berkelanjutan.

Penyebab kerusakan tanah dapat disebabkan oleh dua faktor, yaitu bersifat alamiah (tanah) dan kegiatan/aktivitas manusia, dimana kedua faktor tersebut, yang menyebabkan tanah terganggu/rusak, sehingga tidak mampu lagi berfungsi sebagai media untuk produksi biomassa secara normal dan produktif. Kegiatan biomassa yang memanfaatkan tanah maupun sumber daya alam lainnya bersifat eksploitatif dan tidak terkendali, dapat mengakibatkan kerusakan tanah untuk produksi biomassa. Hal ini berakibat pada penurunan produksi biomassa sehingga menurunkan mutu serta fungsi tanah yang pada akhirnya dapat mengancam kelangsungan kehidupan manusia dan mahluk hidup lainnya (Zhu, 2015).

Tanah merupakan satu komponen lahan berupa lapisan teratas kerak bumi, yang terdiri dari bahan mineral dan bahan organik serta mempunyai sifat fisik, kimia, biologi dan mempunyai kemampuan menunjang kehidupan manusia dan mahluk hidup lainnya. Adapun lahan adalah suatu wilayah daratan yang ciri-cirinya merangkum semua tanda pengenal biosfer, atmosfir, tanah, geologi, timbulan (relief), hidrologi, populasi tumbuhan, dan hewan serta hasil kegiatan manusia masa lalu dan masa kini yang bersifat mantap atau mendaur (Hardjowigeno, 1992).

Melihat dan memahami problematika yang terjadi di Kabupaten Kuningan, yang secara topografi dan geografis merupakan kawasan dataran tinggi (pegunungan), dengan keragaman potensi didalamnya, terutama untuk budidaya tanaman pangan maupun non pangan, maka pencegahan kerusakan tanah untuk produksi biomassa adalah upaya untuk mempertahankan kondisi tanah melalui cara-cara yang tidak memberi peluang berlangsungnya kerusakan tanah,pengelolaannya bersifat ramah lingkungan, atau tidak memberi peluang berlangsungnya kerusakan tanah. Penanggulangan kerusakan tanah merupakan bagian dari upaya yang terus dilakukan, untuk menghentikan atau minimalisir semakin meluasnya kerusakan tanah yang akhirakhir ini terjadi. Proses pemulihan (restorasi maupun konservasi) kondisi tanah adalah upaya untuk mengembalikan kondisi tanah ke tingkatan yang lebih optimal atau tidak rusak.

Berdasarkan hal tersebut di atas diperlukan data dan informasi tingkat kerusakan tanah yang terjadi melalui Sistem Informasi Geografi (SIG). Hasil analisis tersebut, bagian dari penyediaan data dan informasi, yang penting dan mendukung atau menunjang dalam mengidentifikasi dan mengiventarisasi keragaman potensi dan kerentanan, sehingga dapat dilakukan langkah pengendalian secara efektif dan efisien, dimana sebagai upaya mewujudkan Kabupaten Kuningan sebagai kawasan agrobisnis yang handal dengan memperhatikan kelestarian lingkungan. Dengan demikian diharapkan tercipta daya dukung sumberdaya hutan dan lahan yang optimal dan lestari, secara berkelanjutan.

\section{METODOLOGI}

Penelitian ini dilakukan dengan pendekatan survai. Tahap penelitian yang dilakukan adalah tahap persiapan dan pengumpulan data sekunder, survai lapang dan pengukuran, dan analisis data serta penyajian hasil. Metode kerja yang dilakukan untuk penilaian tingkat kekritisan lahan adalah berdasarkan pada dokumen Petunjuk Teknis Penyusunan Data Spasial Lahan Kritis tahun 2004 oleh Direktorat Jenderal Rehabilitasi Lahan dan Perhutanan Sosial (RLPS) dan Surat Direktur Jenderal RLPS No. S.296/V-SET/2004 tanggal 5 Oktober 2004. 
Lokasi kegiatan mencakup wilayah barat Kabupaten Kuningan Provinsi Jawa Barat. Yang terdiri atas lima kecamatan dan sepuluh desa, yaitu : (1) Kecamatan Darma (Desa Gunungsirah dan Desa Sagarahiyang); (2) Kecamatan Cigugur (Desa Puncak, Desa Babakan Mulya dan Desa Cisantana); (3) Kecamatan Jalaksana (Desa Sangkanherang, Desa Sayana dan Desa Sukamukti); (4) Kecamatan Mandirancan (Desa Seda, Desa Trijaya, dan Desa Sukasari); dan (5) Kecamatan Pasawahan (Desa Padabeunghar).

\section{Persiapan dan Survai Lapang}

Persiapan yang dilakukan meliputi studi literatur, hasil-hasil penelitian dan sumber-sumber lain yang relevan. Persiapan ini bertujuan mengetahui kondisi umum daerah penelitian dan langkah-langkah yang perlu dilakukan untuk mencapai tujuan penelitian. Selain itu dilakukan pengumpulan data sekunder yang terdiri atas data curah hujan tahunan, peta administrasi, peta penggunaan lahan, peta kelas lereng dan peta jenis tanah, data kependudukan dan sosek serta data lain yang menunjang.

Survei lapangan dilakukan untuk mengamati dan mengumpulkan data biofisik di daerah penelitian. Plot pengamatan ditentukan berdasarkan hasil overlay antara peta tanah, peta penggunaan lahan dan peta kelas lereng; overlay peta tersebut menghasilkan beberapa satuan lahan. Selanjutnya tiap satuan lahan yang diperoleh dijadikan plot pengamatan intensif untuk pengambilan data biofisik. Plot lokasi pengamatan intensif yang telah ditentukan di peta dicocokkan di lapangan dengan menggunakan GPS.

\section{Analisis Data}

Teknik utama yang digunakan dalam analisis adalah dengan metoda overlay/tumpang susun dan pengecekan/survey langsung di lapanga terhadap beberapa data spasial yang merupakan parameter penentu kekritisan lahan. Parameter penentu kekritisan lahan berdasarkan SK Dirjen RRL No. 041/Kpts/V/1998 meliputi: kondisi tutupan vegetasi, kemiringan lereng, tingkat bahaya erosi dan singkapan batuan (outcrop), dan kondisi pengelolaan (manajemen).

Data spasial lahan kritis dapat disusun apabila data spasial tersebut di atas sudah disusun terlebih dahulu. Data spasial untuk masing-masing parameter harus dibuat dengan standar tertentu guna mempermudah proses analisis spasial untuk menentukan lahan kritis. Standar data spasial untuk masing-masing parameter meliputi kesamaan dalam sistem proyeksi dan sistem koordinat yang digunakan serta kesamaan data atributnya. Teknik overlay analisis lahan kritis dapat dilihat Gambar 1.

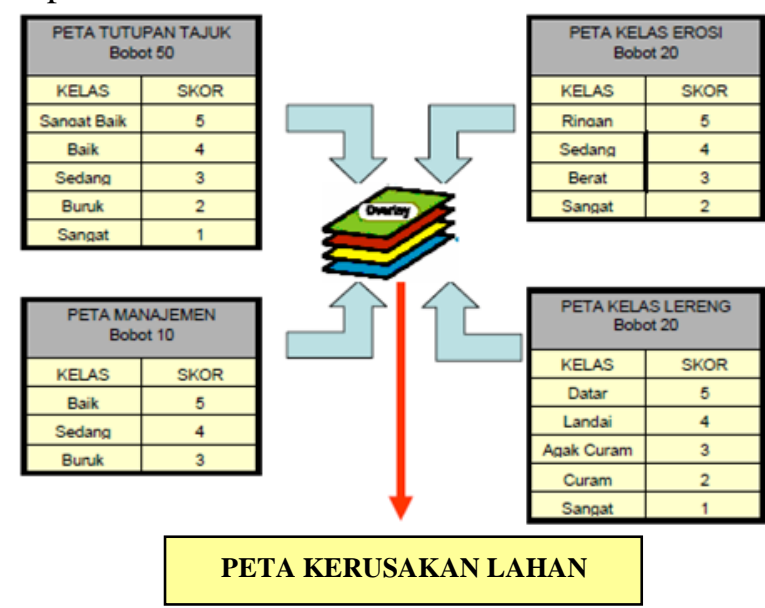

Gambar 1. Teknik overlay analisis lahan kritis

\section{a. Analisis Data Spasial Liputan Lahan}

Informasi tentang liputan lahan dapat diperoleh dari hasil interpretasi citra dengan penginderaan jauh. Citra satelit dapat digunakan sebagai sumber data yang terpercaya untuk pemetaan liputan lahan pada skala 1: 250.000 atau lebih kecil. Hasil interpretasi citra dari Badan Planologi Dep. Kehutanan yang terbaru merupakan sumber data utama liputan lahan tersebut, apabila hasil interpretasi citra satelit yang terbaru tidak tersedia di Bappedda atau instansi terkait lainnya. Dalam penentuan kekritisan lahan, parameter liputan lahan mempunyai bobot $50 \%$, sehingga nilai skor untuk parameter ini merupakan perkalian antara skor dengan bobotnya (skor x 50). Klasifikasi tutupan lahan dan skor untuk masingmasing kelas ditunjukkan pada Tabel 1 .

Data spasial liputan lahan yang disusun harus mempunyai data atribut yang menjelaskan tentang kondisi tutupan lahan pada setiap unit pemetaannya (poligon liputan lahan). Untuk keperluan tersebut, pada data atribut perlu dibuat minimal tiga field (kolom) baru dengan spesifikasi seperti pada Tabel 2 .

Tabel 1. Klasifikasi liputan lahan dan skornya

\begin{tabular}{lccc}
\hline Kelas & $\begin{array}{c}\text { Prosentase } \\
\text { Tutupan } \\
\text { Tajuk (\%) }\end{array}$ & Skor & $\begin{array}{c}\text { Skor x } \\
\text { Bobot } \\
(50)\end{array}$ \\
\hline $\begin{array}{l}\text { Sangat } \\
\text { Baik }\end{array}$ & $>80$ & 5 & 250 \\
\hline Baik & $61-80$ & 4 & 200 \\
\hline Sedang & $41-60$ & 3 & 150 \\
\hline Buruk & $21-40$ & 2 & 100 \\
\hline $\begin{array}{l}\text { Sangat } \\
\text { Buruk }\end{array}$ & $<20$ & 1 & 50 \\
\hline
\end{tabular}


Tabel 2.. Spesifikasi data atribut pada data spasial liputan lahan

\begin{tabular}{|c|c|c|c|c|c|}
\hline \multirow{2}{*}{$\begin{array}{l}\text { Nama } \\
\text { Kolom }\end{array}$} & \multicolumn{4}{|c|}{ Spefisikasi Kolom } & \multirow{2}{*}{$\begin{array}{c}\text { Keterang } \\
\text { an }\end{array}$} \\
\hline & Tipe & Lebar & & $\begin{array}{c}\text { Desim } \\
\text { al }\end{array}$ & \\
\hline $\begin{array}{c}\text { Kelas_V } \\
\text { eg }\end{array}$ & $\begin{array}{c}\text { String } \\
\text { /charact } \\
\text { er }\end{array}$ & 20 & 2 & - & $\begin{array}{c}\text { Diisi kelas } \\
\text { tutupan } \\
\text { lahan }\end{array}$ \\
\hline Tutupan & $\begin{array}{c}\text { C String } \\
\text { /charact } \\
\text { er }\end{array}$ & 10 & 2 & - & $\begin{array}{c}\text { Diisi } \\
\text { prosentase } \\
\text { tutupan } \\
\text { tajuk }\end{array}$ \\
\hline $\begin{array}{c}\text { Skor_Ve } \\
\mathrm{g}\end{array}$ & $\begin{array}{l}\text { Number } \\
\text { /numeric }\end{array}$ & 5 & 5 & - & $\begin{array}{c}\text { Diisi skor } \\
\text { tutupan } \\
\text { lahan }\end{array}$ \\
\hline
\end{tabular}

\section{b. Analisis Data Spasial Kemiringan Lahan}

Data spasial kemiringan lereng disusun dari hasil pengolahan data kontur dalam format digital. Data kontur terlebih dahulu diolah untuk menghasilkan model elevasi digital (Digital Elevation Model/DEM) untuk kemudian diperoses guna menghasilkan data kemiringan lereng. Selain itu data kemiringan lereng juga diperoleh dari data RTL-RLKT yang ada digital kelas kemiringan lerengnya hal ini untuk menghindari terjadinya perbedaan data kelas kemiringan lereng. Klasifikasi kemiringan lereng dan skor untuk masing-masing kelas ditunjukkan pada Tabel 3.

Data spasial kemiringan lereng yang disusun harus mempunyai data atribut yang berisikan informasi kemiringan lereng dan klasifikasinya pada setiap unit pemetaannya (poligon kemiringan lereng), sehingga atribut data spasial kemiringan lereng perlu dibuat dengan spesifikasi seperti pada Tabel 4.

Tabel 3. Klasifikasi lereng dan skoringnya untuk Penentuan

\begin{tabular}{lcc}
\hline \multicolumn{1}{c}{ Kelas } & $\begin{array}{l}\text { Kemiringan } \\
\text { Lereng }(\%)\end{array}$ & Skor \\
\hline Datar & $<8$ & 5 \\
\hline Landai & $8-15$ & 4 \\
\hline Agak Curam & $16-25$ & 3 \\
\hline Curam & $26-40$ & 2 \\
\hline Sangat Curam & $>40$ & 1 \\
\hline
\end{tabular}

Tabel 4. Spesifikasi data atribut pada data spasial kemiringan lereng

\begin{tabular}{|c|c|c|c|c|}
\hline \multirow{2}{*}{$\begin{array}{l}\text { Nama } \\
\text { Kolom }\end{array}$} & \multicolumn{3}{|c|}{ Spefisikasi Kolom } & \multirow{2}{*}{$\begin{array}{c}\text { Keteranga } \\
n\end{array}$} \\
\hline & Tipe & $\begin{array}{c}\text { Leba } \\
\mathrm{r}\end{array}$ & $\begin{array}{c}\text { Desima } \\
1\end{array}$ & \\
\hline $\begin{array}{l}\text { Kelas_Leren } \\
\mathrm{g}\end{array}$ & $\begin{array}{l}\text { String } \\
\text { /Characte } \\
r\end{array}$ & 20 & - & $\begin{array}{l}\text { Diisi kelas } \\
\text { kemiringan } \\
\text { lereng }\end{array}$ \\
\hline
\end{tabular}

\begin{tabular}{llccl}
\hline Kemiringan & $\begin{array}{l}\text { String } \\
\text { /Characte }\end{array}$ & 10 & - & $\begin{array}{l}\text { Diisi nilai } \\
\text { kemiringan } \\
\text { lereng }\end{array}$ \\
\hline Skor_Ler & $\begin{array}{l}\text { Number } \\
\text { /numerik }\end{array}$ & 5 & - & $\begin{array}{l}\text { Diisi skor } \\
\text { kemiringan }\end{array}$ \\
\hline
\end{tabular}

\section{c. Analisis Data Spasial Tingkat Erosi}

Data spasial tingkat erosi diperoleh dari pengolahan data spasial sistem lahan (land system). Setiap poligon (unit pemetaan) land system mempunyai data atribut yang salah satunya berisikan informasi tentang bahaya erosi.

Tingkat erosi pada suatu lahan dalam penentuan lahan kritis di bedakan menjadi 4 kelas yaitu: ringan, sedang, berat dan sangat berat. Klasifikasi tingkat erosi dan skor untuk masingmasing kelas tingkat erosi ditunjukkan pada Tabel 5.

Untuk penentuan lahan kritis, klasifikasi erosi pada land system harus dikonversi sesuai dengan klasifikasi erosi dalam penentuan lahan kritis menurut SK Dirjen RRL No. 041/Kpts/V/1998, seperti ditunjukkan pada Tabel 6.

Penyesuaian klas erosi tersebut dimaksudkan untuk memfokuskan lokasi survey lapangan untuk identifikasi dan inventarisasi erosi aktual dan keberadaan batu-batuan (outcrop). Didalam input data spasial, atribut data spasial tingkat erosi harus mempunyai spesifikasi data seperi pada Tabel 7.

Tabel 5. Klasifikasi tingkat erosi dan skornya untuk penentuan lahan kritis.

\begin{tabular}{clc}
\hline Kelas & \multicolumn{1}{c}{ Besaran / Deskripsi } & Skor \\
\hline Ringan & $\begin{array}{l}\text { Tanah dalam }(>60 \mathrm{~cm}):<25 \% \text { lapisan } \\
\text { tanah atas hilang dan/atau erosi alur } \\
\text { pada jarak } 20-50 \mathrm{~m}\end{array}$ & 5
\end{tabular}
pada jarak $20-50 \mathrm{~m}$

Tanah dangkal $(<60 \mathrm{~cm}):<25 \%$ lapisan tanah atas hilang dan/atau erosi alur pada jarak $>50 \mathrm{~m}$

Sedang Tanah dalam $25-75 \%$ lapisan tanah 4 atas hilang dan/atau erosi alur pada jarak kurang dari $20 \mathrm{~m}$

Tanah dangkal 25 - $50 \%$ lapisan tanah atas hilang dan/atau erosi alur dengan jarak $20-50 \mathrm{~m}$

Berat Tanah dalam Lebih dari $75 \%$ lapisan 3 tanah atas hilang dan/atau erosi parit dengan jarak 20-50 m

Tanah dangkal $50-75 \%$ lapisan tanah atas hilang

Sangat Tanah dalam Semua lapisan tanah atas

Berat hilang $>25 \%$ lapisan tanah bawah dan/atau erosi parit dengan kedalaman sedang pada jarak kurang dari $20 \mathrm{~m}$ 
Tanah dangkal $>75 \%$ lapisan tanah atas telah hilang, sebagian lapisan tanah bawah telah tererosi

Tabel 6.. Reklasifikasi klas erosi menurut land system menyesuaikan klas erosi menurut SK Dirjen RRL No. 041/Kpts/V/1998.

\begin{tabular}{ll}
\hline $\begin{array}{c}\text { Klas Erosi Menurut } \\
\text { SK Dirjen RRL } \\
\text { No. }\end{array}$ & Klas Erosi Menurut Land System \\
$041 /$ Kpts/V/1998 & \\
\hline Ringan & Slight erosion hazard \\
\hline Sedang & Moderately severe erosion hazard \\
\hline Berat & \begin{tabular}{l} 
Severe erosion hazard \\
\hline Sangat Berat
\end{tabular} \\
& $\begin{array}{l}\text { Very severe erosion hazard, extremely } \\
\text { severe erosion hazard, dan } \text { eroded land } \\
\text { system }\end{array}$ \\
\hline
\end{tabular}

Tabel 7. Spesifikasi data atribut pada data spasial tingkat erosi

\begin{tabular}{|c|c|c|c|c|}
\hline \multirow{2}{*}{$\begin{array}{l}\text { Nama } \\
\text { Kolom }\end{array}$} & \multicolumn{3}{|c|}{ Spefisikasi Kolom } & \multirow[t]{2}{*}{ Keterangan } \\
\hline & Tipe & Lebar & Desimal & \\
\hline Kelas_Erosi & $\begin{array}{l}\text { String } \\
\text { /Character }\end{array}$ & 20 & - & $\begin{array}{ll}\text { Diisi } & \text { kelas } \\
\text { erosi }\end{array}$ \\
\hline Deskripsi & $\begin{array}{l}\text { String } \\
\text { /Character }\end{array}$ & 50 & - & $\begin{array}{l}\text { Diisi } \\
\text { keterangan } \\
\text { mengenai } \\
\text { erosi }\end{array}$ \\
\hline Skor_Erosi & $\begin{array}{l}\text { Number } \\
\text { /numeric }\end{array}$ & 5 & - & $\begin{array}{l}\text { Diisi skor } \\
\text { tingkat erosi }\end{array}$ \\
\hline
\end{tabular}

\section{d. Analisis Data Spasial Kriteria Manajemen}

Manajemen merupakan salah satu kriteria yang dipergunakan untuk menilai kekritisan lahan di kawasan hutan lindung, yang dinilai berdasarkan kelengkapan aspek pengelolaan yang meliputi keberadaan tata batas kawasan, pengamanan dan pengawasan serta dilaksanakan atau tidaknya penyuluhan. Data tersebut diperoleh melalui checking lapangan dengan sistem sampling. Data hasil survei tersebut diolah untuk dijadikan sebagai updating data yang sudah ada. Sesuai dengan karakternya, data tersebut juga merupakan data atribut. Seperti halnya dengan kriteria produktivitas, manajemen pada prinsipnya merupakan data atribut yang berisi informasi mengenai aspek manajemen (Tabel 8).

Seperti halnya dengan data spasial kriteria penyusuanan lahan kritis yang lain, data spasial kriteria manajemen yang disusun harus mempunyai data atribut yang berisikan informasi mengenai aspek manajemen dan klasifikasinya pada setiap unit pemetaannya, sehingga atribut data spasial kriteria manajemen perlu dibuat dengan spesifikasi seperti ditunjukkan pada Tabel 9 .
Tabel 8. Klasifikasi manajemen dan skoringnya untuk penentuan lahan kritis

\begin{tabular}{llcc}
\hline Kelas & $\begin{array}{c}\text { Besaran/ } \\
\text { Deskripsi }\end{array}$ & Skor & $\begin{array}{c}\text { Skor x } \\
\text { Bobot } \\
(10)\end{array}$ \\
\hline Baik & Lengkap *) & 5 & 50 \\
\hline Sedang & $\begin{array}{l}\text { Tidak } \\
\text { Lengkap }\end{array}$ & 3 & 30 \\
\hline Buruk & Tidak Ada & 1 & 10
\end{tabular}

*) : - Tata batas kawasan ada

- Pengamanan pengawasan ada

- Penyuluhan dilaksanakan

Tabel 1.10. Spesifikasi data atribut pada data spasial Manajemen

\begin{tabular}{clccl}
\hline \multirow{2}{*}{ Nama } & \multicolumn{2}{c}{ Spefisikasi Kolom } & Keterangan \\
\cline { 2 - 4 } Kolom & \multicolumn{1}{c}{ Tipe } & Lebar & Desimal & \\
\hline Kelas_Mnj & $\begin{array}{l}\text { String } \\
\text { /Character }\end{array}$ & 20 & - & $\begin{array}{l}\text { Diisi kelas } \\
\text { manajemen }\end{array}$ \\
\hline Deskripsi & $\begin{array}{l}\text { String } \\
\text { /Character }\end{array}$ & 20 & - & $\begin{array}{l}\text { Diisi } \\
\text { deskripsi } \\
\end{array}$ \\
& & & $\begin{array}{l}\text { aspek } \\
\text { manajemen }\end{array}$ \\
\hline Skor_Mnj & $\begin{array}{l}\text { Number } \\
\text { Inumeric }\end{array}$ & 5 & - & $\begin{array}{l}\text { Diisi skor } \\
\text { aspek } \\
\text { manajemen }\end{array}$ \\
\hline
\end{tabular}

\section{e. Analisis Skor Total}

Guna memungkinkan analisis yang lebih luas untuk kepentingan rehabilitasi hutan dan lahan, maka skoring kekritisan lahan dalam SK Dirjen RRL No. 041/Kpts/V/1998 perlu diperluas mencakup seluruh fungsi hutan dan di luar kawasan hutan sebagai berikut :

1. Total skor untuk kawasan hutan lindung dapat disetarakan untuk Kawasan Hutan Lindung dan kawasan hutan konservasi.

2. Total skor untuk kawasan budidaya pertanian dapat disetarakan untuk areal penggunaan lain (di luar kawasan hutan).

3. Total skor untuk kawasan lindung di luar kawasan hutan dapat disetarakan untuk kawasan hutan produksi (hutan produksi tetap/produksi yang dapat dikonversi dan hutan produksi terbatas).

Metode yang digunakan untuk menghasilkan total skor adalah tumpangsusun (overlay) data spasial, skor dari setiap parameter tersebut kemudian dijumlahkan. Hasil penjumlahan skor selanjutnya diklasifikasikan untuk menentukan tingkat kekritisan lahan. Klasifikasi tingkat kekritisan lahan berdasarkan jumlah skor parameter kekritisan lahan seperti ditunjukkan pada Tabel 10. 
Tabel 10. Klasifikasi tingkat kekritisan lahan berdasarkan total skor

\begin{tabular}{|c|c|c|c|}
\hline \multicolumn{3}{|c|}{ Total Skor Pada : } & \multirow{2}{*}{$\begin{array}{c}\text { Tingkat } \\
\text { Kekritisan } \\
\text { Lahan }\end{array}$} \\
\hline $\begin{array}{l}\text { Kawasan } \\
\text { Hutan } \\
\text { Lindung }\end{array}$ & $\begin{array}{l}\text { Kawasan } \\
\text { Budidaya } \\
\text { Pertanian }\end{array}$ & $\begin{array}{c}\text { Kawasan } \\
\text { Lindung di } \\
\text { Luar } \\
\text { Kawasan } \\
\text { Hutan }\end{array}$ & \\
\hline $120-180$ & $115-200$ & $110-200$ & Sangat Kritis \\
\hline $181-270$ & $201-275$ & $201-275$ & Kritis \\
\hline $271-360$ & $276-350$ & $276-350$ & Agak Kritis \\
\hline $361-450$ & $351-425$ & $351-425$ & $\begin{array}{c}\text { Potensial } \\
\text { Kritis }\end{array}$ \\
\hline $451-500$ & $426-500$ & $426-500$ & Tidak Kritis \\
\hline
\end{tabular}

\section{HASIL DAN PEMBAHASAN}

\section{Kondisi dan Status Kerusakan Tanah}

Identifikasi kondisi tanah di lokasi penelitian juga dilakukan dengan menggunakan teknik overlay/tumpang susun terhadap beberapa data spasial sumberdaya yang merupakan parameter penentu kekritisan lahan. Parameter penentu kekritisan lahan berdasarkan SK Dirjen RRL No. 041/Kpts/V/1998 meliputi: kondisi tutupan vegetasi, kemiringan lereng, tingkat bahaya erosi dan singkapan batuan (outcrop), dan kondisi pengelolaan (manajemen).

Data spasial lahan kritis dapat disusun apabila data spasial tersebut di atas sudah disusun terlebih dahulu. Data spasial untuk masing-masing parameter harus dibuat dengan standar tertentu guna mempermudah proses analisis spasial untuk menentukan lahan kritis. Standar data spasial untuk masing-masing parameter meliputi kesamaan dalam sistem proyeksi dan sistem koordinat yang digunakan serta kesamaan data atributnya.

Berdasarkan hasil penelitian, dapat diidentifikasi bahwa hampir seluruh desa (12 desa lokasi penelitian) secara umum mengalami kondisi dan status kerusakan yang masuk dalam potensi "sedang". Desa-desa yang lebih banyak berada dalam potensi kerusakan sedang adalah Desa Cisantana, Desa Gunungsirah, Desa Padabeunghar, Desa Puncak, Desa Sangkanherang, Desa Sayana, Desa Seda, Desa Segarahiang, Desa Sukamukti, Desa Sukasari, dan Desa Trijaya. Sedangkan Desa Babakan Mulya lebih banyak berada dalam potensi kerusakan ringan. Kondisi ini diakibatkan oleh kondisi perubahan penggunaan dan tutupan lahan.

Desa Babakan Mulya berada di dalam wilayah administratif Kecamatan Cigugur. Hampir seluruh desa telah didominasi oleh penggunaan selain hutan, yakni sawah irigasi dan permukiman. Selain itu juga didominasi oleh kelas lereng $<8 \%$. Kondisi ini yang menyebabkan bahwa potensi kerusakan di desa ini relatif ringan (Gambar 2).

Desa Cisantana berada di dalam wilayah administratif Kecamatan Cigugur. Lahan di seluruh desa telah banyak beralih fungsi. Ada beberapa lahan yang diperuntukkan untuk hutan lindung banyak yang beralih menjadi kebun campuran dan hutan tanaman rakyat. Selain itu juga banyak yang telah beralih fungsi menjadi sawah irigasi dan permukiman. Desa ini juga didominasi oleh kelas lereng $>15 \%$. Kondisi ini yang menyebabkan bahwa potensi kerusakan di desa ini dominan sedang (Gambar 3).

Desa Gunungsirah berada di dalam wilayah administratif Kecamatan Darma. Lahan di seluruh desa telah banyak beralih fungsi. Lahan di Desa Gunungsirah saat ini banyak didominasi oleh sawah irigasi dan ladang/tegalan. Desa ini juga didominasi kelas lereng > $15 \%$. Kondisi ini menyebabkan bahwa potensi kerusakan di desa ini dominan sedang (Gambar 4).

Desa Padabeunghar berada dalam wilayah adminstratif Kecamatan Pasawahan. Lahan di seluruh desa lebih banyak didominasi oleh lahan terbuka dan kebun/tegalan. Desa ini juga didominasi oleh kelas lereng $>15 \%$. Kondisi ini menyebabkan bahwa potensi kerusakan di desa ini dominan sedang (Gambar 5).

Desa Puncak berada dalam wilayah adminstratif Kecamatan Cigugur. Lahan di seluruh desa lebih banyak didominasi oleh hutan, sawah irigasi, dan kebun. Desa ini juga didominasi oleh kelas lereng > $15 \%$. Kondisi ini menyebabkan bahwa potensi kerusakan di desa ini dominan sedang (Gambar 6).

Desa Sangkanherang berada dalam wilayah administratif Kecamatan Jalaksana. Lahan di seluruh desa lebih banyak didominasi oleh hutan dan kebun. Desa ini juga didominasi oleh kelas lereng > $25 \%$. Kondisi ini menyebabkan bahwa potensi kerusakan di desa ini dominan sedang (Gambar 7).

Desa Sayana berada di wilayah administratif Kecamatan Jalaksana. Lahan di seluruh desa lebih banyak didominasi oleh hutan dan kebun. Desa ini juga didominasi oleh kelas lereng $>25 \%$. Kondisi ini menyebabkan bahwa potensi kerusakan di desa ini dominan sedang (Gambar 8).

Desa Seda berada di wilayah administratif Kecamatan Mandirancan. Lahan di seluruh desa lebih banyak didominasi oleh hutan, ladang/tegalan, lahan terbuka, dan semak belukar. 
Desa ini juga didominasi oleh kelas lereng $>8 \%$. Kondisi ini menyebabkan bahwa potensi kerusakan di desa ini dominan ringan hingga sedang (Gambar 9).

Desa Sagarahiang berada di wilayah adminstratif Kecamatan Darma. Lahan di seluruh desa lebih banyak didominasi oleh hutan, ladang/tegalan, kebun, dan sawah irigasi. Desa ini juga didominasi oleh kelas lereng $>15 \%$. Kondisi ini menyebabkan bahwa potensi kerusakan di desa ini dominan ringan hingga sedang (Gambar 10).

Desa Sukamukti berada di wilayah adminstratif Kecamatan Jalaksana. Lahan di seluruh desa lebih banyak didominasi oleh hutan dan kebun. Desa ini juga didominasi oleh kelas lereng $>15 \%$. Kondisi ini menyebabkan bahwa potensi kerusakan di desa ini dominan sedang (Gambar 11).

Desa Sukasari berada di wilayah adminstratif Kecamatan Mandirancan. Lahan di seluruh desa lebih banyak didominasi oleh sawah tadah hujan. Desa ini juga didominasi oleh kelas lereng $<8 \%$. Kondisi ini menyebabkan bahwa potensi kerusakan di desa ini dominan ringan hingga sedang (Gambar 12).

Desa Trijaya berada di wilayah adminstratif Kecamatan Mandirancan. Lahan di seluruh desa lebih banyak didominasi oleh hutan, sawah tadah hujan, kebun, dan tegalan/ladang. Desa ini juga didominasi oleh kelas lereng $<8 \%$. Kondisi ini menyebabkan bahwa potensi kerusakan di desa ini dominan ringan hingga sedang (Gambar 13).

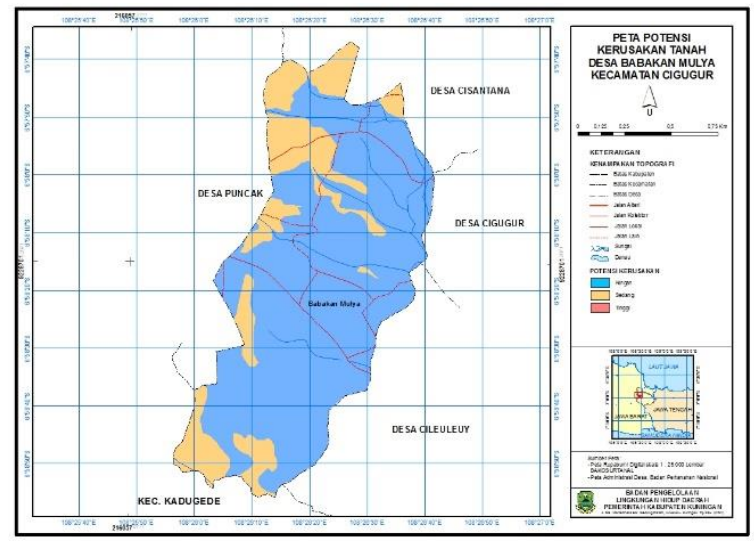

Gambar 2. Potensi kerusakan biomassa di Desa Babakan Mulya

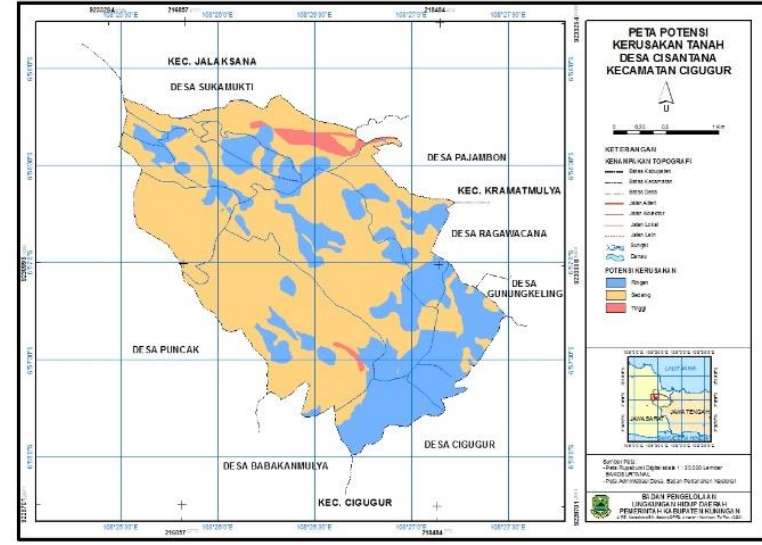

Gambar 3. Potensi kerusakan biomassa di Desa Cisantana

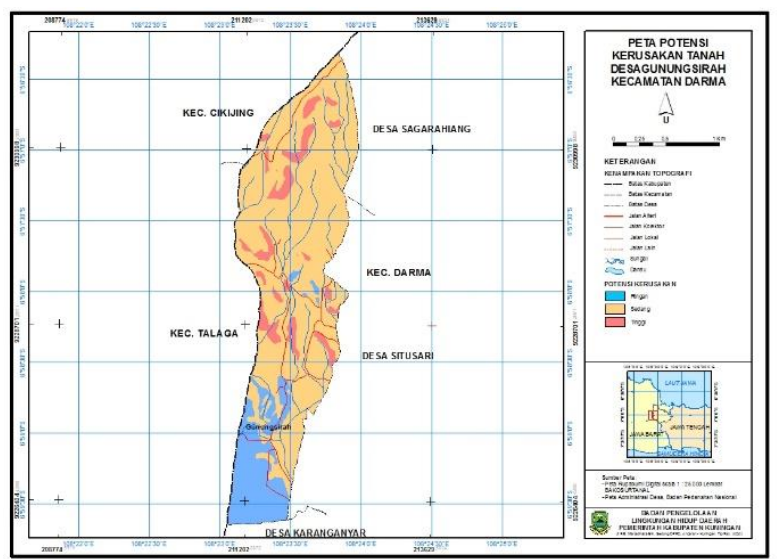

Gambar 4. Potensi kerusakan biomassa di Desa Gunungsirah

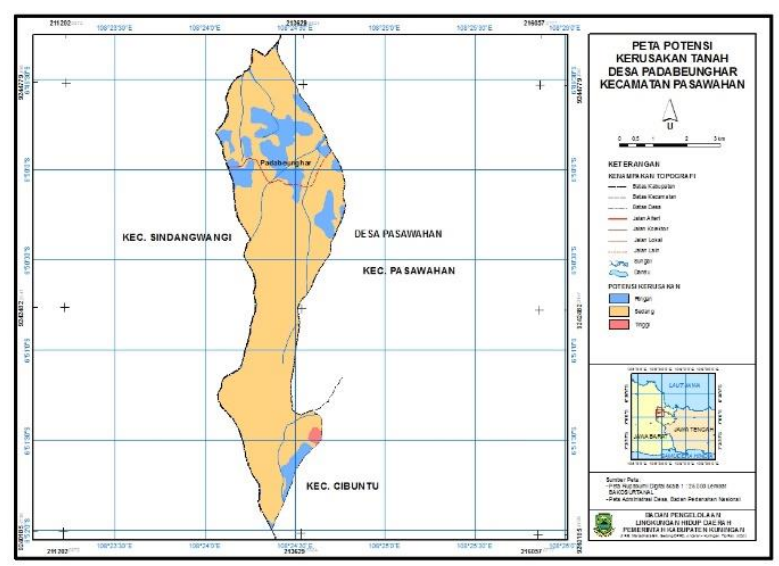

Gambar 5. Potensi kerusakan biomassa di Desa Padabeunghar 


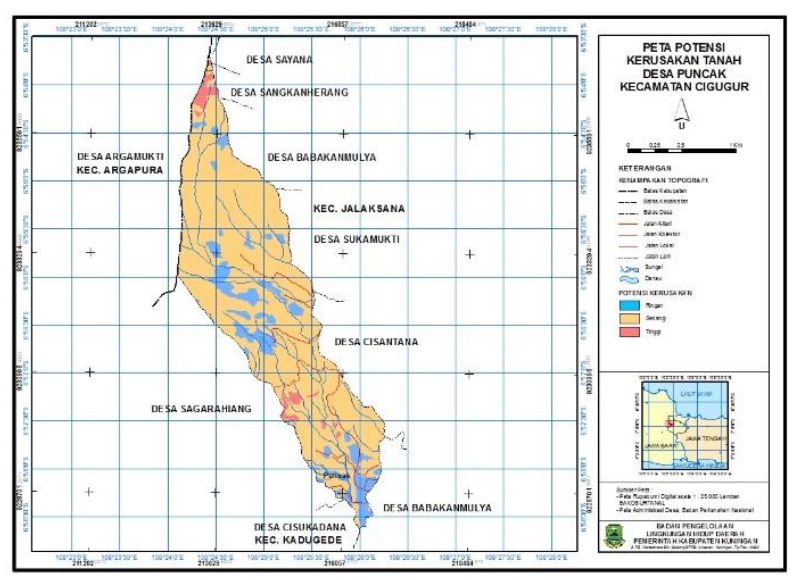

Gambar 6. Potensi kerusakan biomassa di Desa Puncak

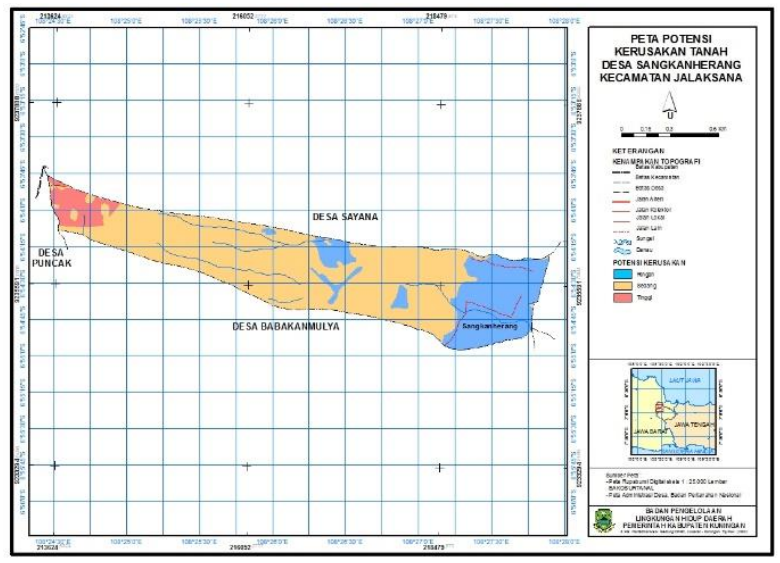

Gambar 7. Potensi kerusakan biomassa di Desa Sangkanherang

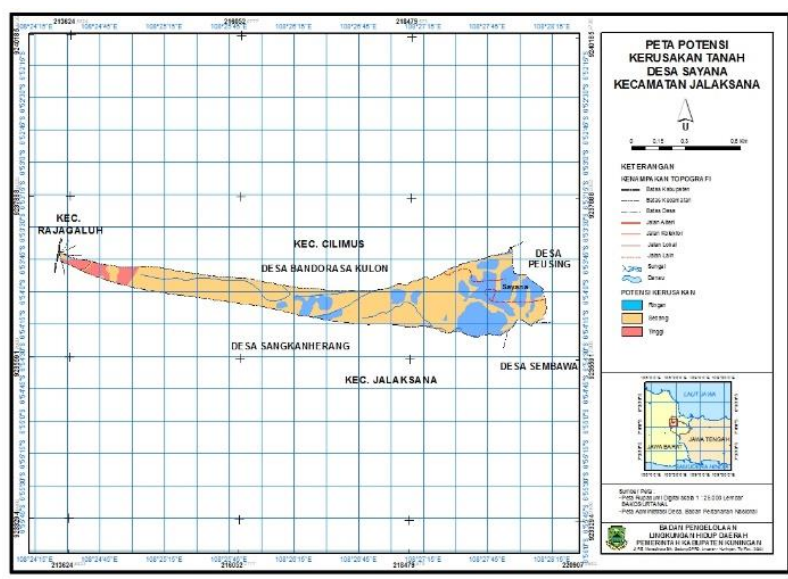

Gambar 8. Potensi kerusakan biomassa di Desa Sayana

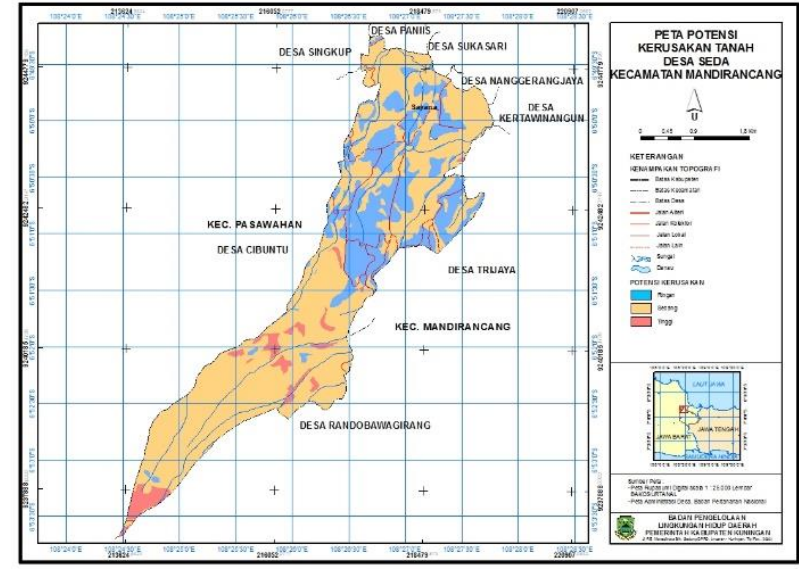

Gambar 9. Potensi kerusakan biomassa di Desa Seda

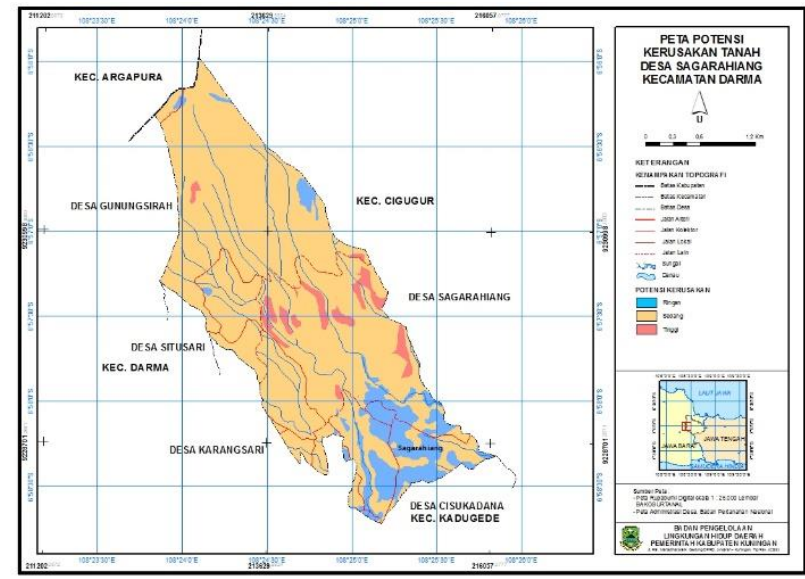

Gambar 10. Potensi kerusakan biomassa di Desa Sagarahiang

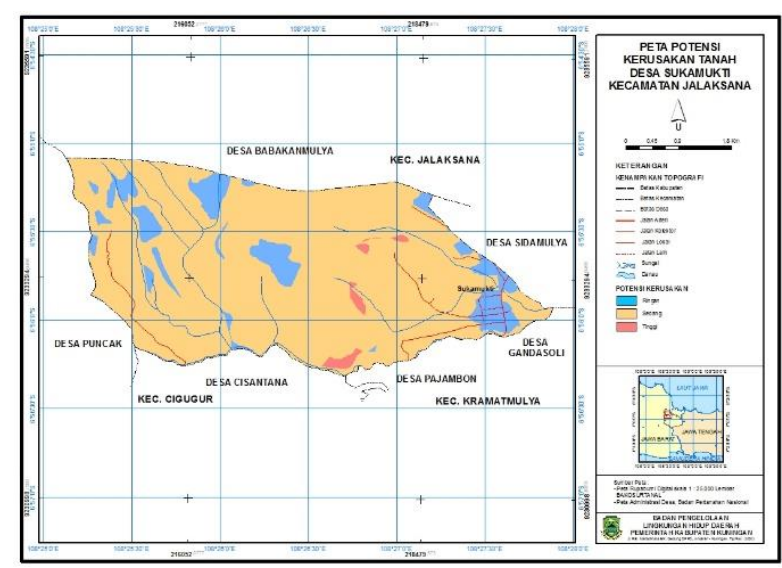

Gambar 11. Potensi kerusakan biomassa di Desa Sukamukti 


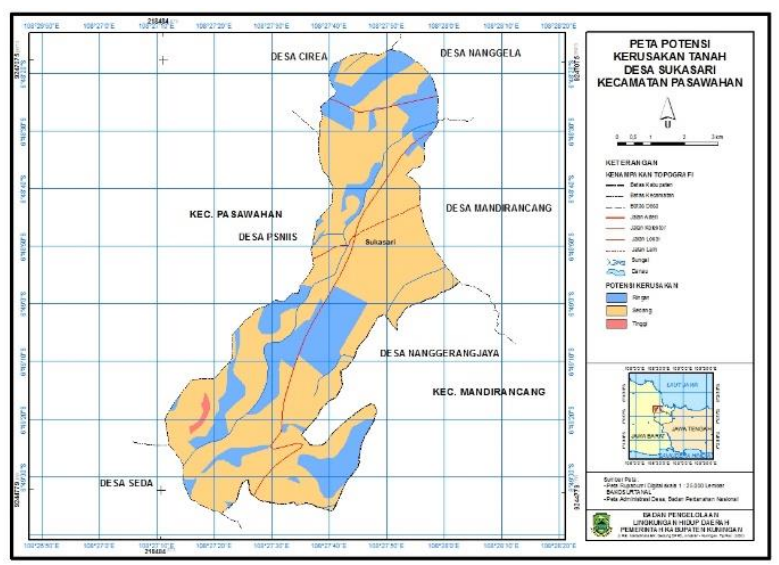

Gambar 12. Potensi kerusakan biomassa di Desa Sukasari

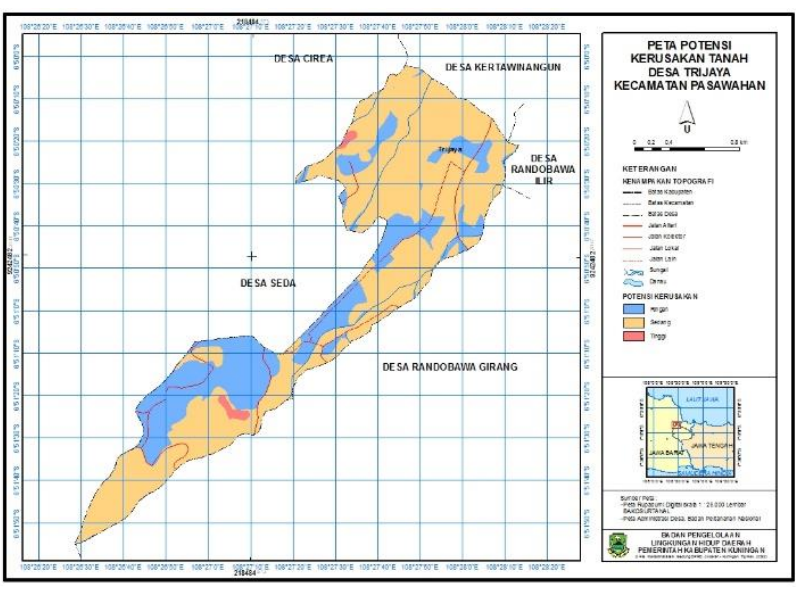

Gambar 13. Potensi kerusakan biomassa di Desa Trijaya

Berdasarkan kriteria baku kerusakan tanah untuk produksi biomassa maka titik-titik sampel tersebut tergolong kedalam status rusak dengan frekwensi relatif tanah rusak $100 \%$, skor frekwensi 4 dan status kerusakan tanah rusak sangat berat.

Berdasarkan penelitian yang dilakukan, menunjukkan bahwa tingkat erodibilitas yang terjadi didaerah penelitian berada pada rentang antara 0,20 sampai dengan 0,73 . Nilai erodibilitas tertinggi dijumpai pada titik sampel di Desa Seda, sedangkan nilai erodibilitas terendah dijumpai pada titik sampel di Desa Sagarahiyang I, Cisantana I dan Trijaya II.

Berdasarkan penelitian yang dilakukan, dapat dilihat bahwa nilai LS dilokasi penelitian berkisar antara 4,25 sampai dengan 9,5. Perbedaan nilai LS masing-masing lokasi titik sampel dipengaruhi oleh persentase kemiringan masingmasing titik sampel. Titik sampel yang mempunyai nilai LS 4,25 ditemui pada delapan titik, sedangkan titik sampel yang mempunyai nilai LS 9,5 ditemui pada dua belas titik sampel.

Hasil perhitungan prediksi erosi tanah, menunjukkan bahwa besarnya erosi yang terjadi berkisar antara $0,68-1.354,18$ ton/ha/tahun. Prediksi erosi tanah yang besarnya kurang dari 1 ton/ha/tahun terjadi di daerah yang dikelola untuk hutan kota. Rendahnya erosi di hutan kota disebabkan hutan kota mempunyai vegetasi yang rapat dan mempunyai tanaman penutup tanah yang rapat sehingga gaya untuk memindahkan air sangat rendah. Erosi terjadi biasanya pada saat pengolahan dan dilakukan pembalikkan tanah sehingga beberapa partikel tanah akan terlepas yang terpindahkan oleh aliran air.

\section{Upaya Penanggulangan Kerusakan Tanah} a. Faktor-Faktor Terjadinya Degradasi Tanah Degradasi tanah pada umumnya disebabkan karena 2 hal yaitu faktor alami dan akibat faktor campur tangan manusia. Degradasi tanah dan lingkungan, baik oleh ulah manusia maupun karena ganguan alam, semakin lama semakin meningkat. Lahan subur untuk pertanian banyak beralih fungsi menjadi lahan non pertanian. Sebagai akibatnya kegiatan-kegiatan budidaya pertanian bergeser ke lahan-lahan kritis yang memerlukan input tinggi dan mahal untuk menghasilkan produk pangan yang berkualitas (Mahfuz, 2003).

Menurut Firmansyah (2003) faktor alami penyebab degradasi tanah antara lain: areal berlereng curam, tanah yang muda rusak, curah hujan intensif, dan lain-lain. Faktor degradasi tanah akibat campur tangan manusia baik langsung maupun tidak langsung lebih mendominasi dibandingkan faktor alami, antar lain: perubahan populasi, marjinalisasi penduduk, kemiskinan penduduk, masalah kepemilikan lahan, ketidakstabilan politik dan kesalahan pengelolaan, kondisi sosial dan ekonomi, masalah kesehatan, dan pengembangan pertanian yang tidak tepat.

Lima faktor penyebab degradasi tanah akibat campur tangan manusia secara langsung, yaitu : deforestasi, overgrazing, aktivitas pertanian, ekploitasi berlebihan, serta aktivitas industri dan bioindustri. Sedangkan faktor penyebab tanah terdegradasi dan rendahnya produktivitas, antara lain : deforestasi, mekanisme dalam usaha tani, kebakaran, penggunaan bahan kimia pertanian, dan penanaman secara monokultur (Lal, 2000). Faktor-faktor tersebut di Indonesia pada umumnya terjadi secara simultan, sebab deforestasi umumnya adalah langkah permulaan degradasi lahan, dan umumnya 
tergantung dari aktivitas berikutnya apakah ditolerenkan, digunakan ladang atau perkebunan maka akan terjadi pembakaran akibat campur tangan manusia yang tidak terkendali (Firmansyah, 2003).

Umumnya faktor-faktor penyebab degradasi baik secara alami maupun campur tangan manusia menimbulkan kerusakan dan penurunan produktivitas tanah. Pada sistem usaha tani tebas dan bakar atau perladangan berpindah masih tergantung pada lama waktu bera agar tergolong sistem usaha yang berkelanjutan secara ekologis. Secara khusus disebutkan bahwa sistem tersebut pada beberapa daerah marjinal dan tekanan populas terhdap lahan cukup tinggi, kebutuhan ekonomi makin meningkat mengakibatkan masa bera makin singkat sehingga sangat merusak dan menyebabkan degradasi tanah dan lingkungan. Banyak penelitian yang menyatakan bahwa setelah 5 tahun sejak pembakaran maka konsentrasi unsur hara menurun, persentase Al tinggi, dan persentase kejenuhan basa rendah di subsoil setelah 2-5 tahun kebakaran. Tanah menjadi subyek erosi, subsoil menjadi media tumbuh tanaman, dan tingginya konsentrasi $\mathrm{Al}$ pada tingkat meracun serta rendahnya kejenuhan basa mendorong penurunan produksi tanaman (Firmansyah, 2003).

Pengaruh antropogenik terhadap degradasi tanah akan sangat tinggi apabila tanah diusahakan bukan untuk non pertanian. Perhitungan kehilangan tanah yang ditambang untuk pembuatan bata merah sangat besar. Akibat penimbunan permukaan tanah dengan tanah galian sumur tambnag emas di Sukabumi mengakibatkan penurunan status hara, menurunkan populasi mikroba dan artropoda tanah, dan merubah iklim mikro (Hidayati, 2000).

Laju deforestrasi di Indonesia sebesar 1,6 juta ha per tahun, sedangkan luas lahan kritis pada awal tahun 2000 keseluruhan seluas 23,2 juta ha (Dephut, 2003). Deforstasi mengakibatkan penurunan sifat tanah. Handayani (1999) menyatakan bahwa deforestrasi menyebabkan kemampuan tanah melepas $\mathrm{N}$ tersedia (amonium dan nitrat) menurun. Degradasi lahan akibat land clearing dan penggunaan tanah untuk pertanaman secara terus-menerus selama 17 tahun memicu hilangnya biotan tanah dan memburuknya sifat fisik dan kimia tanah.

Dibandingkan tanah non terdegradasi, maka terdegradasi lebih rendah $38 \% \mathrm{C}$ organik tanah, 55\% lebih rendah basa-basa dapat ditukar, $56 \%$ lebih rendah biomass mikroba, $44 \%$ lebih rendah kerapatan mikroartropoda, sebaliknya $13 \%$ lebih tinggi berat isi dan $14 \%$ pasir. Nilai $\mathrm{pH}$ non terdegradasi lebih tinggi daripada tanah terdegradasi. Begitu pula ditemukan bahwa dekomposisi daun dan pelepasan unsur hara lebih rendah pada tanah terdegradasi daripada non terdegradasi selama 150 percobaan (Firmansyah, 2003).

Kebakaran hutan seringkali terjadi di Indonesia, data menunjukkan bahwa luas kebakaran hutan pada tahun 2002 sebesar 35.496 ha (Dephut, 2003). Kebakaran menyebabkan perubahan warna agregat luar memiliki hue dan chroma lebih rendah dan hue menjadi lebih merah dibandingkan warna dalam agregat. Selama itu terjadi penurunan Cadd dan meningkatkan kejenuhan Al. Penggunaan warna tanah setelah kebakaran untuk menduga kesuburan tanah sangat terbatas, sebab kesuburan tanah berubah lebih cepat darpada warna tanah (Firmansyah, 2003). Kebakaran juga menyebabkan meningkatnya ammonium, $\mathrm{P}$ tersedia, $\mathrm{Na}+\mathrm{K}+, \mathrm{Mg} 2+$, menurunya nitrat, KTK dan $\mathrm{Ca} 2+$, serta bahan organik, sedangkan erosi akibat kebakaran dapat berkisar sekitar 56 dan 45 kali lebih tinggi dibandingkan dengan tanah tidak terbakar masingmasing pada intensitas tinggi dan sedang (Garcia et a.1, 2000).

\section{Karakteristik Tanah yang Terdegradasi}

Secara jujur pada umumnya kita lebih senang membanggakan kesuburan tanah kita dan keberhasilan pertanian dengan panen melimpah serta lingkungan yang indah dan berkualitas. Sebaliknya kita enggan membicarakan usaha pertanian yang suram atau menurunnya produkstivitas suatu lahan. Sehingga terkesan, bahwa kita melalaikan pelestarian usaha pertanian. Padahal kenyataannya lahan pertanian kita terus terancam oleh degradasi dari segala arah, yang jauh dari kemampuan kebanyakan para petani untuk menangkalnya (Adi, 2003).

Kondisi iklim di Indonesia seperti curah hujan dan suhu yang tinggi, khususnya Indonesia bagian barat, menyebabkan tanah-tanah di Indonesia didominasi oleh tanah marginal dan rapuh serta mudah terdegradasi menjadi lahan kritis. Namun degradasi lebih banyak disebabkan karena adanya pengaruh intervensi manusia dengan pengelolaan yang tidak mempertimbangkan kemampuan dan kesesuian suatu lahan. Kemampuan tanah untuk mendukung kegiatan usaha pertanian atau pemanfaatn tertentu bervariasi menurut jenis tanah, tanaman dan faktor 
lingkungan. Oleh karenanya pemanfaatan tanah ini harus hati-hati dan disesuaikan dengan kemampuannya, agar tanah dapat dimanfaatkan secara berkelanjutan dan tanpa merusak lingkungan (Subika, 2002).

Karakteristik tanah terdegradasi umumnya diukur dengan membandingkan dengan tanah non terdegradasi yaitu tanah hutan. Perbandingan tanah hutan sebagai tanah non terdegradasi karena memiliki siklus tertutup artinya semua unsur hara di dalam sistem tanah hutan berputar dan sangat sedikit yang hilang atau keluar dari sistem siklus hutan. Sedangkan selain tanah hutan merupakan sistem terbuka dimana siklus hara dapat hilang dari sistem tersebut. Penurunan sifat pada tanah untuk penggunaan non hutan akan menunjukkan memburuknya sifat-sifat dari tanah tersebut (Firmansyah, 2003).

Handayani (1999) menyatakan bahwa tanah Ultisol Bengkulu di vegetasi hutan habis tebang 4 bulan dan tanah pertanian yang diusahakan 3 tahun terjadi penurunan kemampuan menyediakan $\mathrm{N}$ anorganik sebesar 12-13\% dubandingkan tanah hutan. Selain itu terjadi penurunan intensitas mineralisasi $\mathrm{N}$ pada lahan pertanian sebesar 39\% pada kedalaman tanah 0-10 $\mathrm{cm}$. Hal ini menunjukkan bahwa tanah hutan mempunyai kemampuan yang lebih tinggi dibandingkan dengan tanah pertanian. Konversi penggunaan lahan hutan ke lahan pertanian telah menyebabkan degradasi pada siklus N. Mengingat begitu luasnya lahan kritis serta laju degradasi yang semakin tinggi, maka usaha-usaha restorasi dan menekan laju lahan kritis sudah menjadi kebutuhan yang cukup mendesak (Subiksa, 2002).

\section{Proses terjadinya Degradasi Tanah}

Problem degradasi tanah dan lingkungan umumnya lebih parah di daerah-daerah tropis daripada daerah temperate, di daerah kering daripada daerah basah, di daerah iklim panas daripada daerah dingin. Diperkirakan diseluruh dunia tanah terdegradasi sekitar 2 milyar hektar dan $75 \%$ berada di daerah tropis. Degradasi tanah dapat disebabkan oleh banyak proses, termasuk erosi tanah yang dipercepat, salinasi, kerusakan karena pertambangan dan aktivitas perkotan, serta pengembalaan berlebih dan komtaminasi dari polutn industri (Widjaja, 2002).

Lima proses utama yang terjadi akibat timbulnya tanah yang terdegradasi, yaitu: menurunnya bahan kandungan bahan organik tanah, perpindahan liat, memburuknya struktur dan pemadatan tanah, erosi tanah, deplesi dan pencucian unsur hara (Firmansyah, 2003). Khusus untuk tanah-tanah tropika basa terdapat tiga proses penting yang menyebabkan terjadinya degradasi tanah, yaitu: 1) degradasi fisik yang berhubungan dengan memburuknya struktur tanah sehingga memicu pergerakan, pemadatan, aliran banjir berlebihan, dan erosi dipercepat, 2) degradasi kimia yang berhubungan dengan terganggunya siklus C, N, P, S dan unsur-unsur lainnya, dan 3) degradasi biologi yang berhubungan dengan menurunya kualitas dan kuantitas bahan organik tanah, aktivitas biotik dan keragaman spesies fauna tanah yang juga menurun ikut menurun (Lal, 2000).

\section{Klasifikasi Tanah yang Terdegradasi}

Tanah merupakan faktor lingkungan penting yang mempunyai hubungan timbal balik dengan tanaman yang tumbuh di atasnya. Tanah yang produktif harus dapat menyediakan lingkungan yang baik seperti udara dan air bagi pertumbuhan akar tanaman disamping harus mampu menyediakan unsur hara yang cukup bagi pertumbuhan tanaman tersebut. Faktor lingkungan tersebut menyangkut berbagai sifat fisik tanah seperti ketersediaan air, temperatur, aerasi dan struktur tanah yang baik (Mahfudz, 2003).

Klasipikasi tanah terdegradasi cukup banyak dimunculkan oleh para ahli diantaranya adalah GLASOD (Globall Asessment of Soil Degradation), suatu proyek yang dirancang UNEP. Klasifikasi GLASOD didasarkan atas keseimbangan antara kekuatan rusak iklim dan resisensi alami kelerengan terhadap kekuatan merusak akibat intervensi manusia. Sehingga dihasilkan penurunan kapasitas tanah saat ini atau kedepan untuk mendukung kehidupan manusia (Firmansyah, 2003).

Tipe degradasi tanah dibagi 2 macam, yaitu : 1) berhubungan dengan displasement bahan tanah yang terdiri dari erosi air dan erosi angin, 2) berdasarkan deterosiasi in situ terdiri dari degradasi kimia (hilangnya unsur hara/bahan organik, salinasi dan polusi), dan degradasi fisik. Derajat tipe degradasi terbagi menjadi rendah sedang, kuat dan ektrim, dengan faktor penyebab adalah deforestasi, overgrazing, kesalahan pengelolan pertanian, ekspoitasi berlebihan, dan aktivitas industri (Firmansyah, 2003).

\section{Pengaruh Degradasi Tanah terhadap Produktivitas \\ Dalam rangka rehabilitasi lahan-lahan} kritis yang luasnya semakin besar di Indonesia serta meningkatnya produktivitas untuk keperluan pertanian, perkebunan, kehutanan dan pelestarian 
alam, maka perlu dilakuakan upaya-upaya yang dapat yang dapat memodifikasi lingkungan tersebut (Subiksa, 2002). Degradasi tanah berpengaruh terhadap penurunan produktivitas tanah. Kehilanagn produktivitas dicirikan dengan terjadinya erosi akibat tanah terdegradasi diperkirakan 272 juta $\mathrm{Mg}$ pangan dunia hilang berdasarkan tingkat produksi tahun 1996 (Lal, 2000).

Tanah yang mengalami kerusakan baik kerusakan karena sifat fisik, kimia dan maupun biologi memiliki pengaruh terhadap penurunan produksi padi mencapai sekitar $22 \%$ pada lahan semi kitis, $32 \%$ pada lahan kritis, dan diperkirakan sekitar $38 \%$ pada lahan sangat kritis. Sedangkan untuk kacang tanah mengalami penurunan sekitar $9 \%, 46 \%, 58 \%$ masing-masing pada tanah semi kritis, kritis dan tanah yang sangat kritis. Sifat tanah yang berkorelasi nyata terhadap produksi padi adalah kedalaman solum, kandungan bahan organik (Sudirman dan Vadari, 2000).

\section{Pentingnya Rehabilitasi Tanah Terdegradasi dalam Upaya Memperpendek Tercapainya Resiliensi dan Meningkatkan Produktivitas}

Resilensi (resilience) merupakan gambaran ukuran kemampuan sistem tanah untuk kembali kepada kondisi asli, sedangkan resiliensi merupakan kemampuan sangga tanah atau ketahanan tanah terhadap perubahan. Konsep resiliensi adalah mengevaluasi kemampuan tanah untuk kembali kepada tingkat penampilan semula, jika tanah tersebut mengalami degradasi atau terjadinya penurunan sifat-sifatnya dalam konteks dimensi waktu dan nilai. Resiliensi merupakan upaya dari rehabilitasi (Firmansyah, 2003), sedangkan Lal (2000) menyatakan bahwa resiliensi tanah tergantung pada keseimbangan antara restorasi tanah dan degradasi tanah. Proses degradasi di lahan kering antara lain memburuknya struktur tanah, gangguan terhadap siklus air, karbon dan hara, sedangkan restorasinya meliputi pembentukan mikroagregat mantap, mekanisme humifikasi dan biomassa $\mathrm{C}$ tanah, meningkatkan cadangan hara dan mekanisme siklus hara, dan keragaman hayati.

Seybold (1999) menyatakan terdapat 3 pendekatan untuk mengkaji resiliensi tanah antara lain: 1) mengukur secara lngsung recovery setelah terjadinya gangguan, 2) melakukan kuantifikasi terpadu mekanisme recovery setelah terjadinya gangguan, dan 3) mengukur sifat-sifat yang mendukung indikator mekanisme recovery tersebut.

Rehabilitasi tanah terdegradasi dapat ditinjau dari sifat tanah yang mengalami penurunan dan diupayakan dilakukan perbaikan dengan menggunakan amelioran. Menurut Firmansyah (2003) bentuk degradasi tanah yang terpenting di Kawasan Asia antara lain adalah adanya erosi tanah, degradasi sifat kimia berupa penurunan bahan organik tanah dan pencucian unsur hara. Degradasi tanah oleh proses erosi permukaan (sheet erosion) telah berlangsung sangat intensif dan meluas di Indonesia. Hal ini terjadi karena: (1) curah hujan yang tinggi, (2) lahan yang berlereng curam, (3) tanah peka erosi, dan (4) praktek pertanian tanpa disertai dengan adanya upaya pengendalian erosi. Di Jawa Barat laju erosi mencapai $5.2 \mathrm{~mm} / \mathrm{thn}$ yang mencakup areal 322 ribu hektar, di Jawa Tengah $15 \mathrm{~mm} / \mathrm{thn}$, di Jawa Timur sekitar $14 \mathrm{~mm} / \mathrm{thn}$, dan di Lampung ditemukan laju erosi $3 \mathrm{~mm} / \mathrm{thn}$. Laju erosi sebesar $1 \mathrm{~mm} / \mathrm{thn}$ setara dengan kehilangan tanah sebanyak 10/ton/ha. Di beberapa wilayah pertanian, selain erosi permukaan juga sering terjadi longsor yang sangat merusak tanah pertanian (Adi, 2003).

Berdasarkan penelitian Herrik dan Wander resiliensi tanah dapat dilakukan berdasarkan kuantifikasi percobaan melalui pengukuran lajunya, atau dikembangkan menjadi recovery setelah gangguan, sedangkan resistensi ditunjukkan sebagai perbandingan kapasitas fungsi tanah setelah gangguan dan kapasitasnya sebelum terganggu. Resistensi tanah dalam istilah ini berhubungan dengan kulitas tanah dalam arti recovery fungsi tanah, sedangkan resistensi tanah berhubungan dengan kualitas tanah dalam arti derajat perubahan tanah dalam fungsi tanah sebagai hasil gangguan. Selama gangguan, kualitas tanah menjadi fungsi resistensi tanah, sedangkan setelah gangguan maka kualitas tanah merupakan fungsi dari resiliensi tanah (Firmansyah, 2003).

\section{Rehabilitasi pada Degradasi Sifat Fisik Tanah}

Degradasi sifat fisik tanah pada umumnya disebabkan karena memburuknya struktur tanah. Kerusakan struktur tanah diawali dengan penurunan kestabilan agregat tanah sebagai akibat akibat dari pukulan air hujan dan kekuatan limpasan permukaan. Penurunan kestabilan agregat tanah berkaintan dengan penurunan 
kandungan bahan organik tanah, aktivitas perakaran dan mikroorganisme tanah. Penurunan ketiga agen pengikat tanah tersebut, selain menyebabkan agregat tanah relatif mudah pecah juga menyebabkan terbentuknya kerak di permukaan tanah (soil crusting) yang mempunyai sifat padat dan keras bila kering. Pada saat hujan turun, kerak yang terbentuk di permukaan tanah juga menyebabkan penyumbatan pori tanah. Akibat proses penyumbatan pori tanah ini, porositas tanah, disribusi pori tanah, dan kemampuan tanah untuk mengalirkan air mengalami penurunan dan limpasan permukaan akan meningkat. Sehingga upaya perbaikan degradasi sifat fisik tanah mengarah terhadap perbaikan struktur tersebut (Suprayogo et al., 2001).

Untuk pengelolaan tanah, tiga strategi dasar yang perlu untuk disarankan adalah (1) eliminasi pengkerakan tanah atas melalui "pengolahan dalam " secara berkala, (2) meningkatan kandungan bahan organik tanah melalui peningkatan jumlah masukan seresah yang bervariasi kualitasnya, dengan cara menanam tanaman penutup tanah atau menanam berbagai jenis pohon, dan (3) peningkatan diversitasi tanaman pohon dalam rangka meningkatkan jumlah dan penyebaran sistem perakaran (Suprayogo et al., 2001).

Firmansyah (2003) menyatakan bahwa penggunaan gambut terhumipikasi rendah dengan BD 0,10 Mg m-3 memilki pengaruh lebih besar daripada gambut terhumifikasi tinggi dengan $\mathrm{BD}$ 0,29 Mg m-3 dalam menurunkan kompaktibilitas tanah. Penelitian tersebut juga menemukan bahwa behan organik lebih efektif untuk tanah dengan kompaktilitas tinggi, ketahanan penetrsai maksimum tanah liat menurun dari 0,64 menjadi $0,30 \mathrm{Mpa}$, dan pada tanah berpasir meningkat dari 0,64 menjadi 1,08 Mpa.

Pemberian bahan tersebut dapat memperbaiki sifat fisik tanah berupa peningkatan total ruang pori, perbaikan aerasi tanah, pori air tersedia, permeabilitas tanah dan menurunnya ketahanan penetrasi. Pemberian dosis $20 \mathrm{Mg} / \mathrm{ha}$ dapat meningkatkan aerasi diatas $12 \%$, sedangkan pada takaran $10 \mathrm{Mg} / \mathrm{ha}$ dapat memperbaiki ketahanan penetrasi (Firmansyah, 2003).

Upaya perbaikan terhadap sifat tanah adalah dalam pemantapan agregat tanah yang memiliki tekstur lepas dengan menggunakan polimer organik. Polyacrilamide (PAM) berberat molekul tinggi dan bermuatan negatif sedang mampu memantapkan permukaan tanah, menurunkan run-of dan erosi. Rehabilitasi tanah terdegradasi dapat ditinjau dari sifat tanah yang mengalami penurunan dan diupayakan dilakukan perbaikan dengan menggunakan amelioran. Bentuk degradasi tanah yang terpenting di kawasan Asia antara lain adalah erosi tanah, degradasi sifat kimia berupa penurunan bahan organik tanah dan pencucian unsur hara (Firmansyah, 2003).

\section{Rehabilitasi terhadap Degradasi Sifat Kimia dan Biologi Tanah}

Perbaikan terhadap lahan yang terdegradasi meliputi penanaman dengan vegetasi asal, penanaman tanaman penutup tanah yang cepat tumbuh, serta dengan penggunaan pupuk organik dan anorganik. Rehabilitasi pada tanah terdegradasi yang dicirikan dengan penurunan sifat kimia dan biologi tanah umumnya tidak terlepas dari penurunan kandungan bahan organik tanah, sehingga amelioran yang umum digunakan berupa bahan organik sebagai agen resiliensi. Pemberian bahan organik jerami atau mucuna sebanyak $10 \mathrm{Mg} / \mathrm{ha}$ dapat memperbaiki sifat-sifat tanah, yaitu meningkatkan aktivitas mikroba, meningkatkan $\mathrm{pH} \mathrm{H} 20$, meningkatkan selisih $\mathrm{pH}$, meningkatkan $\mathrm{pH} \mathrm{NaF}$ (mendorong pembentukan bahan anoganik tanah yang bersifat amorf), meningkatkan $\mathrm{pH} 8,2$ atau KTK variabel yang tergantung $\mathrm{pH}$, menurunkan Aldd dan meningkatkan C-organik tanah. Penurunan Aldd selain disebabkan oleh kenaikan $\mathrm{pH}$ dan pengikatan oleh bahan-bahan tanah bermuatan negatif, juga disebabkan karena pengkhelatan senyawa humit. Peranan asam fulvik dalam mengkhelat Al jauh lebih tinggi dibandingkan asam humik sekitar tiga kalinya (Widjaja, 2002).

Lal (2000) menyatakan bahwa dalam pertanian tradisional maka pemanfaatan cover crop pada masa bera dapat meningkatkan produktivitas tanah berliat aktivitas rendah di tropika basah diperkirakan dapat memfiksasi 172 $\mathrm{kg} / \mathrm{N}$ dari atmosfir selama siklus 2 tahun. Penelitian lainnya yang menggunakan tanaman penutup tinggi ybahwa Leucochepphala dan Acacia leptocarpa merupakan spesies yang menjanjikan untuk ditanam saat masa bera dengan tujuan regenerasi tanah di tropika basah. Tingginya polifenol yang dihasilkan dari serasah daum mampu mengikat protein selama dekomposisi daun, sehingga terjadi immobilisasi $\mathrm{N}$, hal tersebut merupakan peranan utama polifenol dalam bahan organik tanah dan peningkatan $\mathrm{N}$ pada tanah terdegradasi.

Bahan organik sebagai bahan rehabilitasi juga didapat dari limbah, terutama limbah industri 
kelapa sawit yang banyak diluar pulau Jawa. Manik (2002) menyatakan bahwa tandan kosong kelapa sawit sebanyak $95 \mathrm{Mg} / \mathrm{ha}$ mampu meningkatkan $\mathrm{pH}$ tanah, kandungan $\mathrm{P}, \mathrm{K}, \mathrm{Mg}$, dan KTK tanah, serta meningkatkan produksi tandan buah segar 16,3\%. Widhiastuti (2002) pemanfaatan limbah cair kelapa swit atau POME (Palm Oil Mill Efflunt) meningkatkan karbon mikroorganisme $\mathrm{C}$-mic, dengan kecenderungan makin lama limbah diaplikasikan kandungan $\mathrm{C}$ mic makin meningkat.

Amelioran lain yang umum digunakan pada tanah-tanah tropika adalah kapur. Pengapuran umumnya ditujukan untuk menetralkan Aldd terutama pada tanaman yang peka terhadap keracunan Al. Biasanya meningkatkan $\mathrm{pH}$ tanah hingga 5,5 sedangkan bila karena keracunan $\mathrm{Mn}$, maka $\mathrm{pH}$ perlu dinaikkan hingga 6,0 (Firmansyah, 2003).

\section{b. Upaya Pencegahan Kerusakan Tanah}

Upaya pencegahan dilakukan sebelum terjadi kerusakan tanah. Pada dasarnya tanah memiliki kemampuan untuk memperbaiki dirinya dari suatu kerusakan. Meskipun demikian, pada tahap lebih lanjut tanah memerlukan upaya yang dapat membantu memperbaikinya. Kerusakan tanah ditandai dengan berkurangnya tingkat kesuburan tanah. Pada wilayah Kabupaten Kuningan secara umum, khususnya di wilayah penelitian kondisi lahan masih cukup memadai secara kualitas (dalam kondisi tidak rusak), namun tetap diperlukan berbagai upaya untuk mencegah terjadinya kerusakan tanah mengingat pemanfaatan lahan pada wilayah hulu semakin progresif sebagai tekanan dari perkembangan penduduk serta pemanfaatan bahan kimia dalam kegiatan pertanian menjadi ancaman terhadap kerusakan tanah. Oleh karena itu, perlu dilakukan berbagai upaya menjaga tingkat kesuburan tanah dapat dilakukan dengan metode mekanik, vegetatif, dan kimia.

\section{Metode Mekanik}

Metoda mekanik adalah upaya yang dilakukan pada tanah (perekayasaan) untuk meningkatkan produktivitas tanah itu sendiri. Metode mekanik yang sering dilakukan diantaranya:

1) Penterasan Lahan Miring (terracering)

Hal ini dlakukan bertujuan untuk mengurangi panjang lereng dan memperkecil kemiringan lereng. Pembuatan terasering bertujuan untuk mengurangi tingkat erosi karena dapat memperlambat aliran air permukaan.

\section{2) Pengelolaan Sejajar Garis Kontur (Contour Tillage)}

Cara ini dilakukan dengan membuat rongga-rongga tanah sejajar kontur dan membentuk igir-igir. Hal itu dapat memperlambat aliran permukaan dan memperbesar kemungkinan air meresap ke dalam tanah. Umumnya vegetasi ditanam dengan sistem tumpang sari.

3) Pembuatan Pematang/Guludan

Pematang/guludan dibuat dengan cara seperti membuat tanggul-tanggul kecil dan saluran air sejajar garis kontur. Pematang tersebut berfungsi menahan laju air sehingga memperbesar kemungkinan air meresap ke dalam tanah.

\section{4) Pembuatan Cekdam}

Pembuatan cekdam atau bendungan kecil bertujuan membendung aliran air permukaan. Material yang tererosi akan bertahan di parit-parit cekdam sehingga lapisan tanah menebal dan kesuburan tanah tidak akan hilang terbawa air.

\section{Metode Vegetatif}

Metode vegetatif adalah upaya yang dilakukan untuk menjaga kesuburan tanah dengan cara memanfaatkan vegetasi. Metode vegetatif sangat baik untuk upaya pelestarian kesuburan tanah. Metode vegetatif umumnya menggunakan cara-cara sebagai berikut:

1) Penghijauan

Kegiatan penghijaun dilakukan dengan cara menanami hutan kembali lahan-lahan yang kehilangan vegetasi penutupnya. Penanaman dilakukan dengan cara menanami bibit pepohonan besar yang dapat tumbuh dengan mudah.

2) Rotasi Tanaman (Crop Rotation)

Kegiatan rotasi tanaman bertujuan untuk mempertahankan kesuburan tanah. Metode ini dilakukan dengan cara memvariasikan jenis tanaman pada saat pergantian masa tanam. Hal ini efektif untuk mencegah berkurangnya jenis unsur hara tertentu.

\section{3) Reboisasi}

Reboisasi dilakukan dengan menanami lahan gundul dengan tanaman keras. Kegiatan ini selain efektif mencegah erosi, hasil kayunya juga dapat dimanfaatkan.

4) Penanaman Tanaman Penutup (Buffering)

Penanaman tanaman penutup adalah menanami lahan dengan tanaman keras seperti pinus dan jati. Hal ini bertujuan untuk menghambat penghancuran tanah lapisan atas oleh air hujan, memperkaya bahan organik, dan menghambat laju erosi. 
5) Penanaman Tanaman Berbasis (Strip Cropping)

Kegiatan penanaman berbasis adalah menanam secara tegak lurus arah aliran atau arah angin. Pada daerah landai jarak tanam diperlebar sedangkan pada daerah miring tanaman dirapatkan.

6) Penanaman Sejajar Garis Kontur (Contour Strip Cropping)

Penanaman sejajar garis kontur adalah mananami lahan searah dengan garis kontur. Hal ini dilakukan dengan tujuan memperbesar kemungkinan air meresap ke dalam tanah dan menghambat laju erosi.

\section{Metode Kimiawi}

Pengawetan tanah dengan metode kimia adalah penggunaan bahan kimia untuk memperbaiki struktur tanah. Beberapa jenis bahan kimia yang sering digunakan antara lain bitumen, krilium, dan soil conditioner. Ketiga bahan kimia tersebut efektif untuk memperbaiki struktur dan memperkuat agregat tanah. Bahan-bahan kimia tersebut memiliki pengaruh berjangka panjang kerena senyawa tersebut tahan terhadap organisme tanah. Selain memperkuat struktur tanah, soil conditioner dapat digunakan untuk meningkatkan permeabilitas dan mengurangi erosi.

\section{c. Upaya Memperbaiki Kerusakan Tanah}

Kerusakan tanah dapat diketahui dari ketidakmampuan tanah untuk digunakan dalam keperluan manusia. Oleh karena itu, untuk mengembalikan kemampuan tanah diperlukan beberapa tindakan yang mampu memperbaiki kerusakannya. Kerusakan tanah dapat ditimbulkan sebagai akibat dari aktivitas alamiah maupun aktivitas manusia seperti pertambangan, penggunaan bahan kimia dalam pertanian secara berlebihan atau terus menerus, kegiatan industry dan aktivitas rumahtangga. Kerusakan dapat ditimbulkan secara perlahan terhadap lahan yang tidak dilakukan recovery setelah memperoleh tekanan dari berbagai aktivitas manusia. Upaya perbaikan yang dapat dilakukan untuk memperbaiki kerusakan tanah antara lain melalui :

1) Rehabilitasi Kerusakan Sifat Fisik Tanah

Kerusakan sifat fisik tanah umumnya diakibatkan oleh memburuknya struktur tanah. Kerusakan struktur dimulai dengan penurunan kestabilan agregat tanah. Hal itu diakibatkan oleh kikisan air hujan dan aliran permukaan. Berkurangnya kualitas kestabilan agregat tanah diiringi penurunan kandungan bahan organik, aktivitas perakaran vegetasi, dan jumlah mikroorganisme tanah. Tindakan untuk memperbaiki kerusakan sifat fisik tanah sebagai berikut :

(a) pengolahan tanah secara berkala untuk menghindari pergerakan tanah.

(b) peningkatan kandungan bahan organiktanah melalui variasi seresah (dedaunan kering) dari vegetasi penutup lahannaya

(c) peningkatan keanekaragaman tanaman untuk memperbaiki sistem persebaran perakaran.

2) Rehabilitasi Kerusakan Sifat Kimia dan Biologi Tanah

Kerusakan tanah pada sifat kimia dan biologi ditandai dengan penurunan kandungan bahan organik dan kenaikan kadar asam tanah. Tindakan perbaikan dilakukan dengan cara antara lain pemberian jerami dan zat kapur. Pemberian jerami dapat meningkatkan aktivitas mikroba yang membusukkan bahan-bahan tanah dan menghasilkan bahan organik. Pemberian zat kapur dapat membantu menetralisasi kadar keasaman pada tanah.

3) Remediasi Pencemaran tanah

Remediasi adalah kegiatan untuk membersihkan permukaan tanah.Dalam hal ini remediasi yang di lakukan bertujuan memperbaik lahan atau tanah yang sudah tercemar. Sebelum dilakukan remediasi, hal yang perlu diketahui adalah: Jenis perusak atau pencemar (organik/ anorganik), terdegredasi/ tidak, berbahaya atau tidak, berapa banyak zat perusak/ pencemar yang telah merusak/ mencemari tanah tersebut, perbandingan Karbon (C), Nitrogen $(\mathrm{N})$, dan Fosfat (P), Jenis tanah, Kondisi tanah (basa, kering) dan telah berapa lama zat perusak terendapkan di lokasi tersebut. Ada dua jenis remediasi tanah :

(a) In situ (on-site)

In situ adalah pembersihan di lokasi.Pembersihan ini lebih murah dan lebih mudah.Jenis remediasi ini terdiri dari pembersihan, venting (injeksi), dan bioremediasi.

(b) Ex situ (off site)

Ex situ meliputi penggalian tanah yang tercemar dan kemudian dibawa ke daerah yang aman. Dari daerah aman, tanah tersebut dibersihkan dari zat pencemar, caranya: Tanah tersebut disimpan di bak/ tangki yang kedap. Kemudian pembersih dipompakan ke bak/ tangki tersebut. Selanjutnya zat perusak/ pencemar dipompakan keluar dari bak yang kemudian diolah dengan instalasi pengolah air limbah. Pembersihan off-site ini jauh lebih mahal dan rumit. 
4) Bioremediasi

Bioremediasi adalah proses pembersihan perusakan atau pencemaran tanah dengan menggunakan mikroorganisme (jamur, bakteri). Bioremediasi bertujuan untuk memecah atau mendegradasi zat pencemar menjadi bahan yang kurang beracun atau tidak beracun (karbondioksida dan air).

Empat teknik dasar yang biasanya digunakan dalam bioremediasi:

(a) Stimulasi aktivitas mikroorganisme asli (di lokasi tercemar) dengan penambahan nutrient, pengaturan kondisi redoks, optimasi $\mathrm{PH}$, dan sebagainya.

(b) Inokulasi (penanaman) mikroorganisme di lokasi tercemar, yaitu mikroorganisme yang memiliki kemampuan biotransformasi khusus.

(c) Penerapan immobilized enzymes.

(d) Penggunaan tanaman (phyroremediation) Proses bioremediasi harus memperhatikan:
(a) Temperatur tanah
(b) Ketersediaan air
(c) Nutrient $(\mathrm{N}, \mathrm{P}, \mathrm{K})$
(d) Perbandingan C:N kurang dari 30:1
(e) Ketersediaan oksigen

\section{d. Upaya Penanggulangan Erosi Tanah 1. Kerusakan di Tempat Terjadinya Erosi}

Kerusakan tanah di tempat terjadinya erosi mengakibatkan terjadinya hal-hal sebagai berikut:

(a) Penurunan produktivitas tanah.

(b) Kehilangan unsur hara (nutrient) yang diperlukan tanaman.

(c) Kualitas tanaman mengalami penurunan.

(d) Laju infltrasi dan kemampuan tanah menahan air berkurang.

(e) Struktur tanah menjadi rusak.

(f) Lebih banyak tenaga yang diperlukan untuk mengolah tanah.

(g) Erosi gully dan tebing (longsor) menyebabkan lahan terbagi-bagi sehingga mengurangi luas lahan yang dapat ditanami.

(h) Pendapatan petani senakin berkurang.

\section{Kerusakan di Tempat Penerima Hasil Erosi}

Erosi dapat memindahkan tanah berikut senyawa-senyawa kimia yang terdapat di dalamnya, seperti unsur-unsur hara tanaman (fosfor atau bahan organik lainnya) atau sisa-sisa pestisida dan herbisida (DDT, atau endrin).

Pengendapan bahan-bahan tanah dan senyawa-senyawa kimia yang dikandungnya dapat menyebabkan terjadinya polusi di tempat tersebut. Adapun pengendapan bahan tanah yang tererosi dapat menyebabkan hal-hal sebagai berikut.

(a) Pendangkalan sungai sehingga kapasitas sungai menurun, akibatnya terjadi fenomena banjir.

(b) Tanah-tanah yang subur terkadang menurun kualitasnya dan menjadi rusak karena tertimbun oleh batu-batuan, pasir, dan kerikil dari tempat lain.

(c) Jika digunakan untuk air minum, air yang kotor tersebut perlu lebih banyak biaya untuk membersihkannya.

(d) Akibat air yang keruh, akan mengurangi fotosintesis jenis dari tanaman air (karena sinar matahari sulit menembus air).

(e) Perubahan-perubahan dalam jumlah bahan yang diangkut memengaruhi keseimbangan sungai tersebut.

(f) Polusi sedimen terkadang dapat memberi pengaruh baik, yaitu jika terjadi pengendapan tanah-tanah yang subur, misalnya tanah-tanah aluvial di sekitar sungai.

\section{Usaha Mengurangi Erosi Tanah}

Usaha yang dilakukan untuk mengurangi erosi tanah adalah dengan menggunakan metode pengawetan tanah. Metode pengawetan tanah pada umumnya dilakukan untuk:

(a) melindungi tanah dari curahan langsung air hujan;

(b) meningkatkan kapasitas infiltrasi tanah;

(c) mengurangi run off (aliran air di permukaan tanah); dan

(d) meningkatkan stabilitas agregat tanah.

Metode pengawetan tanah dibagi menjadi tiga jenis, yaitu sebagai berikut :

1) Metode vegetatif, adalah metode pengawetan tanah dengan cara menanam vegetasi (tumbuhan) pada lahan yang dilestarikan. Metode ini sangat efektif dalam pengontrolan erosi.

Ada beberapa cara mengawetkan tanah melalui metode vegetatif, antara lain sebagai berikut.

(a) Penghijauan, yaitu penanaman lahan kosong dengan berbagai jenis vegetasi (tanaman).

(b) Reboisasi, yaitu penanaman kembali hutan gundul dengan jenis tanaman keras, seperti pinus, jati, rasamala, dan cemara.

(c) Penanaman secara kontur yaitu menanami lahan searah dengan garis kontur. Fungsinya 
untuk menghambat kecepatan aliran air dan memperbesar tingkat resapan air ke dalam tanah.

(d) Penanaman tumbuhan penutup tanah (bufering), yaitu menanam lahan dengan tumbuhan keras, seperti pinus dan jati.

(e) Penanaman tanaman secara berbaris (strip cropping), yaitu melakukan penanaman berbagai jenis tanaman secara berbaris (larikan). Fungsinya untuk mengurangi tingkat kecepatan erosi.

(f) Pergiliran tanaman (crop rotation), yaitu penanaman jenis tanaman secara bergantian (bergilir) dalam satu lahan. Jenis tanamannya disesuaikan dengan musim. Fungsinya untuk menjaga agar tingkat kesuburan tanah tidak berkurang.

2) Metode Mekanik/Teknik, adalah metode pengawetan tanah melalui teknik-teknik pengolahan tanah yang dapat memperlambat aliran permukaan (run off), menampung, dan menyalurkan aliran permukaan dengan kekuatan tidak merusak.

Beberapa cara yang umum dilakukan pada penerapan metode mekanik, antara lain sebagai berikut :

(a) Pengolahan tanah menurut garis kontur (contour village), yaitu pengolahan tanah sejajar garis kontur. Fungsinya untuk menghambat aliran air dan memperbesar daya resapan air.

(b) Pembuatan tanggul atau guludan sejajar dengan kontur. Fungsinya agar air hujan dapat tertampung.

(c) Pembuatan teras (terrassering), yaitu membuat teras-teras (tangga-tangga) pada lahan miring dengan lereng yang panjang. Fungsinya untuk memperpendek panjang lereng, memperbesar resapan air, dan mengurangi tingkat erosi.

(d) Pembuatan saluran air (drainase). Saluran pelepasan air ini dibuat untuk memotong lereng panjang menjadi lereng yang pendek sehingga aliran air dapat diperlambat.

Metode pengawetan tanah akan sangat efektif jika metode mekanik dapat dikombinasikan dengan metode vegetatif misalnya, terrassering dan bufering.

3) Metode Kimia, dilakukan dengan menggunakan media bahan kimia untuk memperbaiki struktur tanah, yaitu meningkatkan kemantapan agregat (struktur tanah).
Tanah dengan struktur yang mantap tidak mudah hancur oleh pukulan air hujan sehingga infltrasi tetap besar dan aliran air permukaan (surface run off) tetap kecil. Penggunaan bahan kimia untuk pengawetan tanah belum banyak dilakukan, walaupun cukup efektif tetapi biayanya mahal. Pada saat ini umumnya masih dalam tingkat percobaan-percobaan. Beberapa jenis bahan kimia yang sering digunakan untuk tujuan ini antara lain dengan menggunakan preparat kimia sintetis (bitumen dan krilium) atau alami. Preparat ini disebut Soil Conditioner atau pemantap struktur tanah. Sesuai dengan namanya Soil Conditioner ini digunakan untuk membentuk struktur tanah yang stabil. Senyawa yang terbentuk akan menyebabkan tanah menjadi stabil.

Kerusakan tanah dapat dikurangi dan dicegah melalui suatu upaya yang disebut konversi tanah. Konversi tanah adalah pemeliharaan dan perlindungan terhadap tanah secara teratur guna mengurangi dan mencegah kerusakan tanah dengan cara pelestarian. Metode konservasi tanah dilakukan dengan 3 cara, yaitu konservasi secara agronomis, mekanis, dan kimiawi :

(a) Konservasi secara agronomis adalah konservasi dengan memanfaatkan vegetasi (tanaman) dan sisa tanaman untuk mengurangi laju perusakan lapisan tanah paling atas.

(b) Konservasi secara mekanis adalah konservasi tanah yang prinsipnya berupaya mengurangi banyaknya tanah yang hilang akibat erosi. Contohnya adalah pembuatan guludan dan terasering.

(c) Konservasi secara kimiawi adalah konservasi tanah dengan memanfaatkan bahan-bahan kimia. Konservasi kimiawi bertujuan untuk memperbaiki kemantapan struktur tanah.

Pada tanah-tanah berlereng, erosi menjadi persoalan yang serius. Dimana kemiringan dan panjang lereng adalah dua unsur lereng yang berpengaruh terhadap aliran permukaan dan erosi. Jika kecepatan aliran meningkat dua kali, maka jumlah butir-butir tanah yang tersangkut menjadi 32 kali lipat, bila panjang lereng menjadi dua kali lipat, maka umumnya erosi yang terjadi akan meningkat 1.5 kali. Pengkajian di Indonesia menunjukkan untuk tanah gundul tingkat erosi mencapai $120-400$ ton/ha/th, hal ini tentu saja di bidang jalan akan memberikan dampak turunan seperi kerusakan prasarana dan sarana jalan. Adapun tujuan pengkajian teknologi penanganan erosi di ruang milik jalan ini adalah untuk mengetahui pengaruh kemiringan lereng dan kombinasi metode vegetatif terhadap tingkat erosi 
pada kemiringan diatas atau dibawah 60 derajat dan Kajian pengembangan teknologi penanganan erosi lereng dengan metode vegetatif (rumput vetiver dan rumput bahia). Untuk mencapai tujuan itu dilakukan pengkajian dan pembuatan prototype skala laboratorium penanganan erosi dengan metode vegetasi (tanaman), dan pengkajian pengembangan teknologi penanganan erosi lereng dengan tanaman rumput vetiver yang dikombinasikan dengan rumput bahia dan rumput gajah dalam skala lapangan. Hasil pengkajian menunjukkan tingkat erosi akan semakin berkurang dengan meningkatnya tingkat kerimbunan tanaman, dan kerimbunan tanaman penutup $>70 \%$ tanah yang tererosi mendekati nol. Teknik Penanaman rumput vetiver agar berfungsi secara optimal di dalam mengurangi tingkat erosi dilereng dilakukan secara berbaris dan diantara baris vetiver ditanamami tanaman penutup rumput bahia.

\section{PENUTUP Simpulan}

Berdasarkan hasil penelitian, dapat diidentifikasi bahwa hampir seluruh desa (12 desa lokasi penelitian) secara umum mengalami kondisi dan status kerusakan yang masuk dalam potensi "sedang". Desa-desa yang lebih banyak berada dalam potensi kerusakan sedang adalah Desa Cisantana, Desa Gunungsirah, Desa Padabeunghar, Desa Puncak, Desa Sangkanherang, Desa Sayana, Desa Seda, Desa Segarahiang, Desa Sukamukti, Desa Sukasari, dan Desa Trijaya. Sedangkan Desa Babakan Mulya lebih banyak berada dalam potensi kerusakan ringan. Kondisi ini diakibatkan oleh kondisi perubahan penggunaan dan tutupan lahan.

Berdasarkan evaluasi, faktor dominan yang mendorong laju kerusakan tanah dilokasi penelitian adalah karena faktor alami dan faktor manusia. Faktor alami mencakup jenis tanah yang rentan terhadap erosi, curah hujan yang tinggi dan kelas lereng yang dominan diatas $8 \%$. Sedangkan faktor manusia yaitu perubahan populasi, marjinalisasi penduduk, kemiskinan penduduk, masalah kepemilikan lahan, sistem pengelolaan lahan yang tidak sesuai dengan kaidah konservasi tanah dan air, kondisi sosial dan ekonomi dan pengembangan pertanian yang tidak tepat.

Semua hal tersebut menyebabkan tanahtanah di Kecamatan Darma (Desa Gunungsirah dan Desa Sagarahiyang); Kecamatan Cigugur (Desa Puncak dan Desa Cisantana); Kecamatan Jalaksana (Desa Sangkanherang, Desa Sayana dan
Desa Sukamukti); Kecamatan Mandirancan (Desa Seda, Desa Sukasari dan Desa Trijaya); dan Kecamatan Pasawahan (Desa Padabeunghar) mengalami kerusakan.

Kondisi lahan masih cukup memadai secara kualitas (dalam kondisi tidak rusak), namun tetap diperlukan berbagai upaya untuk mencegah terjadinya kerusakan tanah mengingat pemanfaatan lahan pada wilayah hulu semakin progresif sebagai tekanan dari perkembangan penduduk serta pemanfaatan bahan kimia dalam kegiatan pertanian menjadi ancaman terhadap kerusakan tanah. Oleh karena itu, perlu dilakukan berbagai upaya menjaga tingkat kesuburan tanah dapat dilakukan dengan metode mekanik, vegetatif, dan kimia.

Upaya perbaikan yang dapat dilakukan untuk memperbaiki kerusakan tanah antara lain melalui rehabilitas kerusakan sifat fisik tanah (pengolahan tanah secara berkala untuk menghindari pergerakan tanah, peningkatan kandungan bahan organik tanah melalui variasi seresah (dedaunan kering) dari vegetasi penutup lahannya, peningkatan keanekaragaman tanaman untuk memperbaiki sistem persebaran perakaran), rehabilitasi kerusakan kimia dan biologi tanah dilakukan dengan cara pemberian jerami dan zat kapur. Pemberian jerami dapat meningkatkan aktivitas mikroba yang membusukkan bahanbahan tanah dan menghasilkan bahan organik. Pemberian zat kapur dapat membantu menetralisasi kadar keasaman pada tanah, remediasi pencemaran tanah, bioremediasi (stimulasi aktivitas mikroorganisme asli (di lokasi tercemar) dengan penambahan nutrient, pengaturan kondisi redoks, optimasi $\mathrm{PH}$, dan sebagainya, inokulasi (penanaman) mikroorganisme di lokasi tercemar, yaitu mikroorganisme yang memiliki kemampuan biotransformasi khusus, penerapan immobilized enzymes, penggunaan tanaman (phyroremediation).

Kerusakan tanah dapat dikurangi dan dicegah melalui suatu upaya yang disebut konversi tanah. Konversi tanah adalah pemeliharaan dan perlindungan terhadap tanah secara teratur guna mengurangi dan mencegah kerusakan tanah dengan cara pelestarian. Metode konservasi tanah dilakukan dengan 3 cara, yaitu konservasi secara agronomis, mekanis, dan kimiawi.

\section{Saran}

Berdasarkan hasil penelitian di beberapa lokasi menunjukkan tingkat kerusakan biomassa 
yang cukup kritis. Hal yang harus segera dilakukan adalah segera dilakukan upaya perbaikan dan pengendaliannya baik secara kimiawi, teknis, dan mekanik.

Untuk mengetahui secara rinci tingkat kerusakan biomassa maka perlu dilakukan penelitian yang lebih mendalam dan detil di setiap desa dengan skala ruang yang lebih rinci. Selain itu, penelitian ini masih dilakukan di wilayah barat Kabupaten Kuningan, maka perlu dilakukan penelitian untuk wilayah lainnya. Selain itu perlu dilakukan analisis laboratorium terhadap kondisi fisik, biologi, dan kimiawi tanah.

\section{UCAPAN TERIMA KASIH}

Penulis mengucapkan terima kasih kepada Badan Pengelolaan Lingkungan Hidup Daerah (BPLHD) Pemerintah Kabupaten Kuningan, Provinsi Jawa Barat yang telah member kesempatan untuk melakukan penelitian. Selain itu diucapkan terima kasih kepada Perpustakaan Institut Pertanian Bogor (IPB) yang telah memberikan kesempatan untuk mengunduh jurnal..

\section{DAFTAR PUSTAKA}

Adi, S. 2003. Degradasi tanah pertanian Indonesia. http://www.sinar tani-online.co.id. 29 Maret 2009

Anas, I. 1989. Biologi Tanah Dalam Praktek. Jurusan Ilmu Tanah Fakultas Pertanian Institut Pertanian Bogor. Bogor.

Bols, P.L.1978. The Isoerodent Map of Java and Madura. Belgium Technical Assistance Project ATA 105. Soil Research Institute.

Dephut.Statistik

Kehutanan, http://www.dephut.org.id/23 september 2003.

Fahmi, A. dan E. Hanudin. 2008. Pengaruh Kondisi Redoks terhadap Stabilitas Kompleks Organik-Besi Pada Tanah Sulfat Masam. Jurnal Ilmu Tanah dan Lingkungan. 8(1):49-55.

Fahma, W, dan Kristyanto. 2018. Penguatan home garden sebagai garda ketahanan pangan berbasis peta kesesuaian lahan dengan aplikasi Maxent, di Kota Tangerang Selatan. Laporan hasil penelitian (Unpublished). UIN Jakarta.

Firmansyah, M. A. 2003. Resiliensi tanah terdegradasi. Makalah pengantar falsapah sain. IPB.

Garcia, E. G. V. Andreu, dan J. L. Rubio. 2000. Chanhe in organic matter, nitrogen, phosporous and cations in soil as aresult of fire and water erosion in a Mediteranean landscape. European Jornal of Soil Science. 51:201-210.

Handayani, I. P. 1999. Kuantitas dan variasi nitrogen tersedia pada tanah setelah penebangan hutan. J. Tanah Trop. 8:215226.

Hardjowigeno, S. 1992. Ilmu Tanah. Akademika Pressindo. Jakarta.

Hardjowigeno, S dan Widiatmaka, 2011. Evaluasi Kesesuaian Lahan dan Perencanaan Tataguna Lahan. Gadjah Mada University Press. Jogyakarta.

Hidayati, N. 2000. Degradasi lahan pasca penambangan emas dan upaya reklamasinya: kasus penambangan emas Jampang-Sukabumi. Prosidng kongres Nasional VII HITI: pemanfaatn sumberdaya tanah sesuai dengan potensinya menuju keseimbanagan lingkungan hidup dalam rangka meningkatkan kesejahteraan rakyat. Bandung 2-4 Nopember 1999. Himpunan tanah Indonesia. Hal: 283-294.

Lal. 2000. Soil management in the developing countris. Soil Science. 165(1):57-72

Latifah, S. 2003. Kegiatan reklamasi tanah pada bekas tambang. Tesis USU. Program Kehutanan. Jurusan manajemen hutan. Universitas Sumatera Utara.

Laurance, WF, Sayer, J, dan Cassman, KG. 2014. Agricultural expansion and its impact ontropical nature. Trends in ecology and evolution, 29 (2), 107-116. Available online:

http://www.sciencedirect.com/science/arti cle/pii/S0169534713002929.

Mahfuz. 2003. Peningkatan produktivitas lahan kritis untuk pemenuhan pangan melalui usaha tani konservasi. Makalah Falsafah Sains. IPB.

Maier, D. 2015. The Great Myth : Why poputaion growth does not necessarily cause environmental degradation and poverty. The Public Sphare, 150-158, Availabel online:

https://pdfs.semanticsecholar.org/8caf/6c 572acb2874189cc7097194d9fda76eb4b7. pdf.

[PP] Peraturan Pemerintah Republik Indonesia No. 150 Tahun 2000 tentang Pengendalian Kerusakan Tanah untuk Produksi Biomassa.

[PP] Peraturan Menteri Lingkungan Hidup Republik Indonesia No. 07 Tahun 2006 
tentang Tata Cara Pengukuran Kriteria Baku Kerusakan Tanah Untuk Produksi Biomassa.

[PPPG] Pusat Penelitian dan Pengembangan Geologi. 1992. Peta Geologi Indonesia. Ditjen Geologi dan Sumberdaya Mineral, Departemen Pertambangan dan Energi Republik Indonesia. Jakarta.

[PPT] Pusat Penelitian Tanah Bogor. 1994. Sistem Lahan RePPPrott. Bogor.

[SK] Surat Keputusan Dirjen RRL Kementerian Kehutanan Republik Indonesia Menurut SK Dirjen RRL No. 041/Kpts/V/1998 tentang Reklasifikasi Klas Erosi Menurut Land System Menyesuaikan Klas Erosi

Rencher, AC. 2002. Methods of Multivariate Analysis. John Wiley \& Sons, Inc.Publ. p. 380-404.

Sutanto, R. 2005. Dasar-dasar Ilmu Tanah: Konsep dan Kenyataan. Penerbit Kanisius. Yogyakarta. 208 hal.

[UU] Undang-Undang Republik Indonesia No. 32 Tahun 2009 tentang Perlindungan dan Pengelolaan Lingkungan Hidup.

Zhum YG dan Mcharg, AA. 2015. Protecting global soil resources for ecosystem services. Ecosystem Heatlh and Sustainability, 1(3),1-4. Avaliable online: http://onlinelibrary.wiley.com/doi/10.189 0/EHS15-0010.1/full. 